\title{
Segregations in Steels during Heat Treatment - A Consideration along the Process Chain*
}

\section{Seigerungen in Stählen während der Wärmebehandlung - Eine Betrachtung entlang der Prozesskette}

\section{Abstract/Kurzfassung}

\begin{abstract}
Segregation is an unavoidable phenomenon in continuous or ingot casting of steel for thermodynamic reasons. If costly processes that explicitly reduce segregation are not carried out, the segregations remain until the final product. Therefore, an understanding of the development and effects of segregation along the entire process chain is necessary. The focus in this publication is on the treatment of segregations in low alloy steels. First, the characterisation of segregation is presented. An overview of the formation and development of segregations during primary shaping and forming processes is given. The focus is on segregation-related effects during heat treatment with regard to inhomogeneous microstructure and negative heat treatment results such as distortion or hardening cracks. In a short outlook, the influence of segregation on the component behaviour is described.
\end{abstract}

Keywords: Segregation, microstructural banding, steel, process chain
Seigerungen sind beim Strang- oder Blockguss von Stahl aus thermodynamischen Gründen eine unvermeidliche Begleiterscheinung. Werden nicht explizit seigerungsabbauende, kostspielige Prozesse durchgeführt, bleiben die Seigerungen bis zum Endprodukt erhalten. Deshalb ist ein Verständnis der Entwicklung und Auswirkungen von Seigerungen über die gesamte Prozesskette notwendig. Dabei liegt der Fokus in dieser Veröffentlichung auf der Behandlung von Seigerungen bei niedrig legierten Stählen. Zunächst wird die Charakterisierung von Seigerungen dargestellt. Es wird eine Übersicht über die Entstehung und Entwicklung von Seigerungen während Ur- und Umformprozessen gegeben. Der Schwerpunkt liegt dabei auf seigerungsbedingten Effekten während der Wärmebehandlung hinsichtlich inhomogenem Gefüge und negativem Wärmebehandlungsergebnis wie Verzug oder Härterisse. In einem kurzen Ausblick wird der Einfluss von Seigerungen auf das Bauteilverhalten beschrieben.

Schlüsselwörter: Seigerungen, Gefügezeiligkeit, Stahl, Prozesskette

Author/Autor: Dr.-Ing. Martin Hunkel, Leibniz-Institut für Werkstofforientierte Technologien - IWT, Badgasteiner Str. 3, 28359 Bremen, hunkel@iwt-bremen.de

HOW TO CITE THIS ARTICLE: M. Hunkel: Segregations in Steels during Heat Treatment - A Consideration along the Process Chain. HTM J. Heat Treatm. Mat. 76 (2021) 2, pp. 79-104, DOI:10.1515/htm-2020-0006

\section{Introduction}

The subject of segregation is an important factor for the heat treater, as it can influence the heat treatment result and have an effect on the component properties. Nevertheless, segregations are not significantly changed during soft annealing or hardening, nor can they be characterised on the undestroyed component. However, segregation is influenced by several process steps along the process chain. Segregation is an inhomogeneous concentration of ele-

\section{Einleitung}

Das Thema Seigerungen ist für den Wärmebehandler ein wichtiger Faktor, da diese das Wärmebehandlungsergebnis beeinflussen und Auswirkungen auf die Bauteileigenschaften haben können. Gleichwohl werden die Seigerungen weder beim Weichglühen oder Härten wesentlich verändert, noch lassen sich diese am unzerstörten Bauteil charakterisieren. Seigerungen werden allerdings durch mehrere Prozessschritte entlang der

\footnotetext{
* Reworked and extended version of a lecture held at the HeatTreatingCongress, HK 2020, 21.-22. October 2020, online
} 


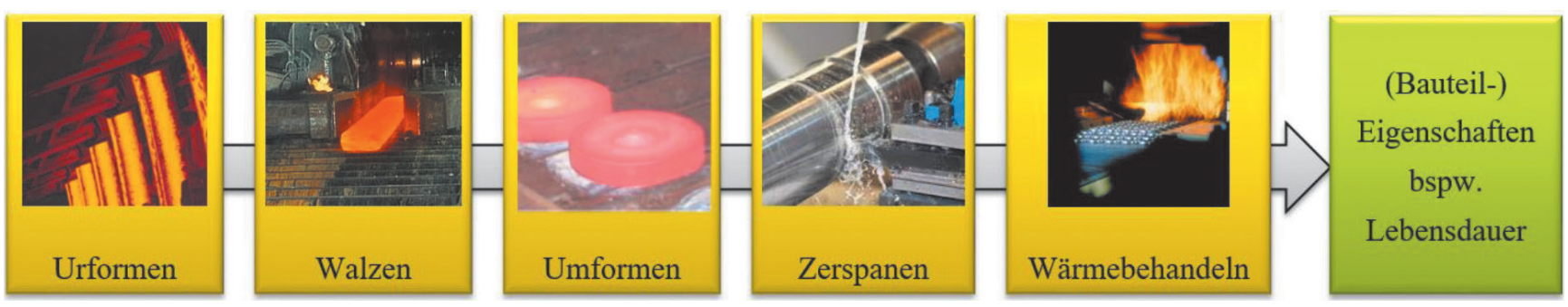

Fig. 1. Simplified process chain for the manufacture of components with the process steps considered in this publication

Bild 1. Vereinfachte Prozesskette zur Herstellung von Bauteilen mit den in dieser Veröffentlichung betrachteten Prozessschritten

ments in steel, e. g. carbon, sulphur, manganese and chromium due to slow heat release during solidification [1]. These can be observed in both ingot casting and continuous casting of slabs and billets. The complexity of segregation is illustrated by the distinction between segregation formation during primary shaping and segregation of the interstitial alloying elements during cooling from primary shaping, forming or heat treatment temperature to room temperature [2]. After cooling to room temperature, the segregation profiles of the substitutional and interstitial alloying elements do not necessarily have to match.

During component manufacture, a number of very different process steps are involved, which have an influence on the heat treatment result via different effects [3]. Ultimately, however, heat treatment is only a means to an end, so that a component fulfils its task in use. Figure 1 shows a simplified process chain with the processes discussed in this publication. Segregations are chemical inhomogeneities that arise from the melt during solidification $[4,5]$. Therefore, the consideration of primary shaping processes is unavoidable. It should already be pointed out here that segregations are thermodynamically unavoidable during solidification. During forming processes, rolling in the steel mill and forging or pressing, segregations are very strongly deformed. During heat treatment, segregations have an influence on phase transformations and can lead to an inhomogeneous microstructure. Ultimately, segregations and especially the resulting microstructural inhomogeneities can have an influence on the component properties. In addition to the processes mentioned, numerous other process steps such as grinding, blasting, coating or joining can be carried out. Particularly during joining, segregations can be changed. But for reasons of space, these processes will not be discussed further.

In practice, segregations after heat treatment can be noticeable by a banded microstructure, fibres or carbide bands. Figure 2 shows two examples of microstructure formation due to segregation. In hypoeutectoid steels, a ferrite/pearlite microstructure is arranged in bands (Figure 2a). In hardened hypereutectoid steels, fibres are found in the macrograph (Figure 2b). In micrograph, carbide bands can be found in hardened hypereutectoid steels. Segregation structures still occur even in pro-
Prozesskette beeinflusst. Sie sind eine inhomogene Konzentration von Elementen in Stahl, z. B. Kohlenstoff, Schwefel, Mangan und Chrom infolge langsamer Wärmeabgabe während der Erstarrung [1]. Diese sind sowohl beim Blockguss als auch beim Strangguss von Brammen und Knüppeln zu beobachten. Die Komplexität der Seigerungen wird durch die Unterscheidung zwischen Seigerungsentstehung beim Urformen und der Entmischung der interstitiellen Legierungselemente beim Abkühlen von Urform-, Umform-, oder Wärmebehandlungstemperatur auf Raumtemperatur verdeutlicht [2]. Nach dem Abkühlen auf Raumtemperatur müssen die Seigerungsprofile der substitutionellen und der interstitiellen Legierungselemente deshalb nicht notwendigerweise übereinstimmen.

Bei der Bauteilherstellung sind etliche, sehr verschiedene Prozessschritte involviert, die über unterschiedliche Effekte einen Einfluss auf das Wärmebehandlungsergebnis haben [3]. Letztlich ist aber auch die Wärmebehandlung nur Mittel zum Zweck, damit ein Bauteil seine Aufgabe im Einsatz erfüllt. Bild 1 zeigt eine vereinfachte Prozesskette mit den in dieser Veröffentlichung behandelten Prozessen. Seigerungen sind chemische Inhomogenitäten, die bei der Erstarrung aus der Schmelze entstehen $[4,5]$. Deshalb ist die Betrachtung von Urformprozessen unumgänglich. Bereits hier sei darauf hingewiesen, dass Seigerungen thermodynamisch bei der Erstarrung unvermeidbar sind. Während Umformprozessen, dem Walzen im Stahlwerk und dem Schmieden oder Pressen werden Seigerungen sehr stark verformt. Bei der Wärmebehandlung haben Seigerungen einen Einfluss auf die Phasenumwandlungen und können zu einem inhomogenen Gefüge führen. Letztlich können Seigerungen und vor allem die daraus erfolgenden Gefügeinhomogenitäten einen Einfluss auf die Bauteileigenschaften haben. Neben den genannten Prozessen können noch zahlreiche weitere Prozessschritte, wie Schleifen, Strahlen, Beschichten oder Fügen, durchgeführt werden. Insbesondere beim Fügen können Seigerungen verändert werden. Aber aus Platzgründen wird auf diese Prozesse nicht weiter eingegangen.

In der Praxis können sich Seigerungen nach einer Wärmebehandlung durch ein zeiliges Gefüge, Fasern oder Karbidzeilen bemerkbar machen. Bild 2 zeigt zwei Beispiele der Gefügeausbildung aufgrund von Seigerungen. Bei untereutektoiden Stählen ist ein Ferrit/Perlit-Gefüge zeilenförmig angeordnet (Bild 2a). Bei gehärteten übereutektoiden Stählen finden sich im Makroschliff Fasern (Bild 2b). Im Mikroschliff lassen sich bei gehärteten übereutektoiden Stählen Karbidzeilen feststellen. Auch bei Prozessen mit sehr 

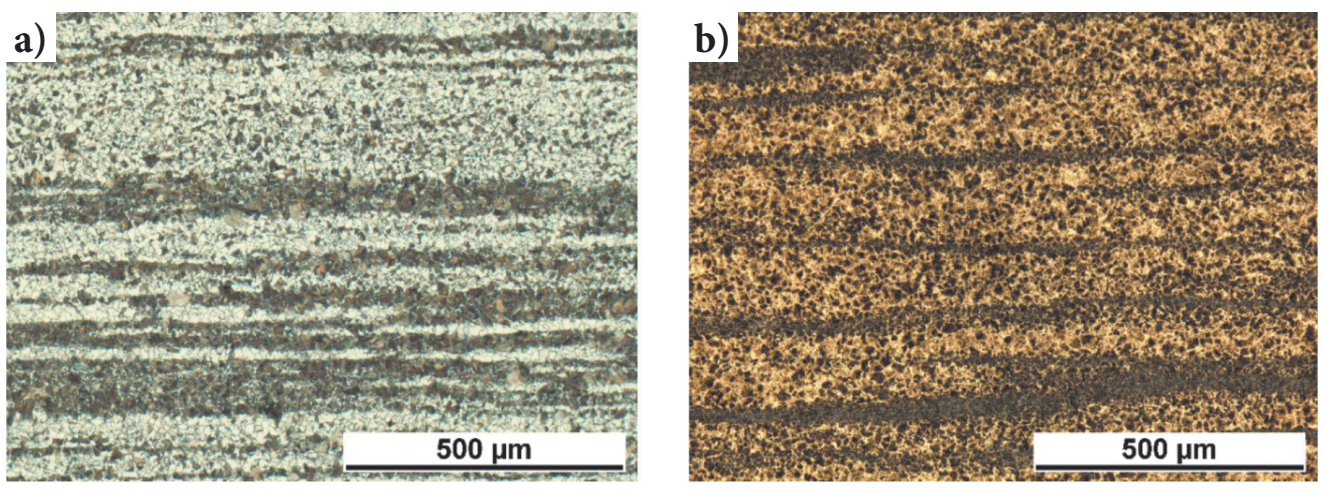

\author{
Fig. 2. Microstructural \\ inhomogeneities caused by \\ segregation a) ferrite/pearlite \\ bands in semi-finished $20 \mathrm{MnCr} 5$, \\ b) fibres in martensitic hardened \\ $100 \mathrm{Cr} 6$
}

Bild 2. Durch Seigerungen bedingte Gefügeinhomogenitäten a) Ferrit/Perlit-Zeilen in Halbzeug $20 \mathrm{MnCr5}$,

b) Fasern in martensitisch gehärtetem $100 \mathrm{Cr} 6$ cesses with very high cooling rates, such as in additive manufacturing [6].

In order to consider segregation along the process chain, ways of characterising segregation will first be described (Chapter 2). In Chapter 3, the formation of segregations during the primary shaping processes follows and in Chapter 4, the possibilities of reducing segregations are explained. Chapter 5 describes the deformation of segregations during forming. Segregations can be cut unfavourably by machining processes and are therefore dealt with in Chapter 6. For reasons of space, only a brief outline of the effects that become relevant for heat treatment can be given in these chapters. The focus is on segregation-related processes in heat treatment (Chapter 7). In this chapter both soft annealing and hardening are discussed. This is followed by a brief discussion of the effect of segregation on component properties (Chapter 8). The focus of the considerations is on the case hardening steel $20 \mathrm{MnCr} 5$. However, the results are easily transferable to other steel grades.

\section{Characterisation of segregations}

\subsection{Classification of segregations}

Due to different formation mechanisms during solidification, segregations are classified differently. Essentially, two size scales are distinguished, whereby the size scales in the semi-finished product depend very sensitively on the solidification speed and the subsequent forming processes. Microsegregations are differences in concentration within dendritic or globulitic areas [7]. Macrosegregations are called long-range decomposition $[8,9]$. The highly enriched residual melt in the core, which solidifies last, forms the core segregation, also called centre decomposition [9]. In addition to the solidification speed, gravity also has an influence. Free-moving, already solidified particles sink downwards in the melt following gravity. This results in a gravity segregation. Gravity segregation occurs in particular in ingot casting [10], but also to a lesser extent in bow-type continuous casting, where it manifests itself, for example, in the form of a displacement of the core segregation relative to the geometric strand centre $[11,12]$. hoher Abkühlgeschwindigkeit, wie bei der additiven Fertigung, treten noch Seigerungsstrukturen auf [6].

Zur Betrachtung der Seigerungen entlang der Prozesskette sollen zunächst Möglichkeiten der Charakterisierung von Seigerungen beschrieben werden (Kapitel 2). In Kapitel 3 folgt die Entstehung der Seigerungen während der Urformprozesse und in Kapitel 4 werden die Möglichkeiten der Reduzierung von Seigerungen ausgeführt. Im Kapitel 5 wird die Verformung von Seigerungen während der Umformung dargestellt. Durch Zerspanprozesse können Seigerungen ungünstig angeschnitten werden und werden deshalb in Kapitel 6 behandelt. Aus Platzgründen kann in diesen Kapiteln nur ein kurzer Abriss der Effekte gegeben werden, die für die Wärmebehandlung relevant werden. Der Schwerpunkt liegt in seigerungsbedingten Vorgängen bei der Wärmebehandlung (Kapitel 7). In diesem Kapitel werden sowohl das Weichglühen als auch das Härten ausgeführt. Es folgt eine kurze Abhandlung der Auswirkung von Seigerungen auf die Bauteileigenschaften (Kapitel 8). Der Schwerpunkt der Betrachtungen liegt dabei auf dem Einsatzstahl 20MnCr5. Die Ergebnisse sind aber problemlos auf andere Stahlgüten übertragbar.

\section{Charakterisierung von Seigerungen}

\subsection{Klassifizierung von Seigerungen}

Aufgrund verschiedener Bildungsmechanismen beim Erstarren werden Seigerungen unterschiedlich eingeteilt. Im Wesentlichen werden zwei Größenskalen unterschieden, wobei die Größenskalen im Halbzeug sehr empfindlich von der Erstarrungsgeschwindigkeit und den nachfolgenden Umformprozessen abhängen. Als Mikroseigerungen werden Konzentrationsunterschiede innerhalb von dendritischen oder globulitischen Bereiche bezeichnet [7]. Makroseigerung werden langreichweitigere Entmischungen genannt $[8,9]$. Die stark verunreinigte Restschmelze im Kern, die zuletzt erstarrt, bildet die Kernseigerung, auch Mittenseigerung genannt [9]. Neben der Erstarrungsgeschwindigkeit hat auch die Schwerkraft einen Einfluss. Frei bewegliche, bereits erstarrte Partikel sinken in der Schmelze der Schwerkraft folgend nach unten. Dadurch entsteht eine Schwerkraftseigerung. Schwerkraftseigerungen treten insbesondere bei Blockguss auf [10], in geringerem Maße aber auch bei Rundbogenstrangguss, wo sie sich bspw. in 
Table 1. Measured effective distribution coefficients of some alloying elements in steel

Tabelle 1. Gemessene effektive Verteilungskoeffizienten einiger Legierungselemente in Stahl
Segregation is described on the one hand with the effective distribution coefficient via the chemical inhomogeneity, i. e. the relation between maximum and minimum concentration, and on the other hand geometrically via the segregation distance of the dendrites and dendrite arms. Both quantities, effective distribution coefficient and segregation spacing, depend strongly on the solidification rate, the chemical composition and the solidification morphology. In addition, both quantities are subject to strong fluctuations even within a component. The chemical inhomogeneity is indicated by the effective distribution coefficient $k_{\text {eff }}[13]$ :

$k_{\text {eff }}=\frac{C_{\text {Dendrit }}}{C_{\text {Inerdendrit }}}$

Here $C_{\text {Dendrit }}$ is the concentration within the dendrites and $C_{\text {Interdendrit }}$ is the concentration between the dendrites. For $k_{e f f}<1$ the segregation is positive and for $k_{e f f}>1$ the segregation is negative. Almost all common alloying elements in steel segregate positively, i. e. they accumulate in the melt. Important exceptions are $\mathrm{Si}, \mathrm{Al}$ (up to about $3 \%), \mathrm{Cu}, \mathrm{Ni}$ or $\mathrm{Co}$, which segregate negatively. The distribution of the chemical elements can be determined with an electron probe microanalyser and thus the effective distribution coefficient can be calculated. Table 1 shows the experimentally determined effective distribution coefficient of some alloying elements in steel. The variation of the effective distribution coefficient due to influencing factors such as solidification rate, chemical composition and solidification morphology, but also analytical accuracy, is greater than the difference between the individual elements. Carbon increases the most. However, the determination of the effective distribution coefficient is difficult due to diffusion in austenite and phase transformations, which is why it was not specified. Stronger segregation occurs above all in $\mathrm{S}$ and $\mathrm{P}$. This then leads to the local formation of sulphides such as $\mathrm{MnS}$ in S-containing steels.

The solidification morphology is often indicated by the secondary dendrite arm spacing $\left(\lambda_{D}\right.$ in $\left.\mu \mathrm{m}\right)$. In addition to the experimental measurement, this can be estimated from the cooling rate during solidification

\begin{tabular}{|c|c|c|}
\hline Element & effektiver Verteilungskoeffizient $k_{\text {eff }}$ & Referenz \\
\hline $\mathrm{S}$ & $0,1-0,5$ & {$[14]$} \\
\hline $\mathrm{P}$ & $0,1-0,5$ & {$[7,14,15]$} \\
\hline $\mathrm{Nb}$ & 0,25 & {$[7,15]$} \\
\hline $\mathrm{Mo}$ & $0,25-0,63$ & {$[16,17]$} \\
\hline $\mathrm{Cr}$ & $0,25-0,9$ & {$[7,14-17]$} \\
\hline $\mathrm{Mn}$ & $0,28-0,72$ & {$[7,14,15,17]$} \\
\hline
\end{tabular}

Form einer Verschiebung der Kernseigerung gegenüber der geometrischen Strangmitte äußern [11, 12].

Seigerungen werden zum einen mit dem effektiven Verteilungskoeffizienten über die chemische Inhomogenität, d.h. die Relation zwischen maximaler und minimaler Konzentration, und zum anderen geometrisch über den Seigerungsabstand der Dendriten und Dendritenarme beschrieben. Beide Größen, effektiver Verteilungskoeffizient und Seigerungsabstand, hängen stark von der Erstarrungsgeschwindigkeit, der chemischen Zusammensetzung und der Erstarrungsmorphologie ab. Zudem sind beide GröBen mit starken Schwankungen auch innerhalb eines Bauteils behaftet. Die chemische Inhomogenität wird durch den effektiven Verteilungskoeffizient $k_{\text {eff }}$ angegeben [13]:

$k_{\text {eff }}=\frac{C_{\text {Dendrit }}}{C_{\text {Inerdendrit }}}$

Dabei ist $C_{\text {Dendrit }}$ die Konzentration innerhalb der Dendriten und $C_{\text {Interdendrit }}$ die Konzentration zwischen den Dendriten. Für $k_{e f f}<1$ ergibt sich eine positive und für $k_{e f f}>1$ ergibt sich eine negative Seigerung. Fast alle üblichen Legierungselemente in Stahl seigern positiv, d.h. sie reichern sich in der Schmelze an. Wichtige Ausnahme sind $\mathrm{Si}$, $\mathrm{Al}$ (bis etwa $3 \%$ ), $\mathrm{Cu}$, Ni oder $\mathrm{Co}$, die negativ seigern. Die Verteilung der chemischen Elemente lässt sich mit einer Elektronenstrahl-Mikrosonde bestimmen und so der effektive Verteilungskoeffizient berechnen. Tabelle 1 gibt den experimentell bestimmten effektiven Verteilungskoeffizienten einiger Legierungselemente in Stahl wieder. Die Variation des effektiven Verteilungskoeffizienten aufgrund von Einflussgrößen wie Erstarrungsgeschwindigkeit, chemischer Zusammensetzung und Erstarrungsmorphologie aber auch Analysegenauigkeit ist dabei größer als der Unterschied zwischen den einzelnen Elementen. Kohlenstoff seigert dabei am stärksten. Die Bestimmung des effektiven Verteilungskoeffizienten ist aber aufgrund der Diffusion im Austenit und bei den Phasenumwandlungen schwierig zu bestimmen, weswegen auf eine Angabe verzichtet wurde. Stärker seigern noch vor allem S und P. Das führt dann bei Shaltigen Stählen zu einer lokalen Bildung von Sulfiden wie MnS.

Die Erstarrungsmorphologie wird oft durch den sekundären Dendritenarmabstand $\left(\lambda_{D}\right.$ in $\left.\mu \mathrm{m}\right)$ angegeben. Neben der experimentellen Messung kann dieser aus der Abkühlgeschwindigkeit beim Erstarren abgeschätzt werden 
$\lambda_{D}=A \times\left(\frac{d T}{d t}\right)^{n}$

where the material-dependent characteristic parameters $\mathrm{A}$ and $\mathrm{n}$ are approximately $\mathrm{A}=35$ and $\mathrm{n}=-0.35$ and $d T / d t$ is given in $\mathrm{K} \mathrm{s}^{-1}$ $[18,19]$. Transferred to usual continuous casting conditions, this results in a secondary dendrite arm spacing of $\lambda_{D}=100-1000 \mu \mathrm{m}$. In high-alloy steels, primary carbide bands often occur, which are characterised with the aid of comparative images according to SEP 1520 [20]. However, primary carbide bands can also occur in low-alloy, higher carbon steels such as $100 \mathrm{Cr} 6$ [21].

With the help of digital image processing, microstructure bands in the rolled semi-finished product can be evaluated automatically [22-25]. In addition to the spacing of the microstructure bands, discontinuous (non-continuous) microstructure features can also be parameterised and thus a degree of homogenisation can be determined. The smaller the difference between these parameters parallel and perpendicular to the band direction, the more homogeneous a material is considered to be.

\subsection{Detection of segregations}

Various methods can be used to detect segregation. The direct examination is carried out by determining the local chemical composition. An indirect determination can be made via metallographic imaging of the microstructure, in which a banding of the microstructure is analysed. As shown in Chapter 7.1, a heat treatment can be carried out in such a way that no representation of the segregations in the microstructure is visible [26]. Therefore, the absence of a banded microstructure does not necessarily mean that the material is free of segregation. Regardless of the measuring method, it is important to observe the correct plane. Often, the segregations are only analysed after rolling, during which the microsegregations are strongly elongated in the rolling direction. Microsegregations can then preferably be observed parallel to the rolling direction. Figure 3 shows the segregation structures of a ferrite-pearlite microstructure of $20 \mathrm{MnCr} 5$ parallel and perpendicular to the rolling direction [27]. The two directions perpendic-
$\lambda_{D}=A \times\left(\frac{d T}{d t}\right)^{n}$

wobei die materialabhängigen Kennwerte $\mathrm{A}$ und $\mathrm{n}$ in etwa $\mathrm{A}=35$ und $\mathrm{n}=-0,35$ betragen und $d T / d t$ in $\mathrm{K} \mathrm{s}^{-1}$ angegeben wird $[18,19]$. Übertragen auf übliche Stranggussbedingungen ergibt sich ein sekundären Dendritenarmabstand von $\lambda_{D}=100-1000 \mu \mathrm{m}$. Bei hochlegierten Stählen treten oft Primärkarbidzeilen auf, die mithilfe von Vergleichsbildern nach SEP 1520 charakterisiert werden [20]. Primärkarbidzeilen können aber auch bei niedriglegierten, höher kohlenstoffhaltigen Stählen wie 100Cr6 auftreten [21].

Mithilfe der digitalen Bildverarbeitung lassen sich vor allem Gefügezeiligkeiten im gewalzten Halbzeug automatisiert auswerten [22-25]. Neben dem Abstand der Gefügezeilen lassen sich auch diskontinuierliche (nicht-durchgängige) Gefügezeiligkeiten parametrisieren und damit ein Homogenisierungsgrad feststellen. Dabei gilt ein Material als umso homogener, je geringer der Unterschied dieser Parameter parallel und senkrecht zur Zeilenrichtung ist.

\subsection{Nachweis von Seigerungen}

Für den Nachweis von Seigerungen können verschiedene Methoden eingesetzt werden. Die direkte Untersuchung erfolgt über die Bestimmung der lokalen chemischen Zusammensetzung. Eine indirekte Bestimmung kann über die metallographische Aufnahme des Gefüges erfolgen, bei der eine Zeiligkeit des Gefüges analysiert wird. Wie in Kapitel 7.1 gezeigt wird, kann eine Wärmebehandlung so durchgeführt werden, dass keine Abbildung der Seigerungen im Gefüge sichtbar ist [26]. Deshalb kann aus dem Fehlen eines zeiligen Gefüges nicht unbedingt auf ein seigerungsfreies Material rückgeschlossen werden. Unabhängig von der Messmethode ist die Beachtung der richtigen Ebene wichtig. Oft werden die Seigerungen erst nach dem Walzen analysiert, bei dem die Mikroseigerungen stark in Walzrichtung gelängt werden. Mikroseigerungen lassen sich dann bevorzugt parallel zur Walzrichtung beobachten. Bild 3 zeigt die Seigerungsstrukturen eines zeiligen Ferrit-Perlit-Gefüges von $20 \mathrm{MnCr} 5$ parallel und senkrecht zur
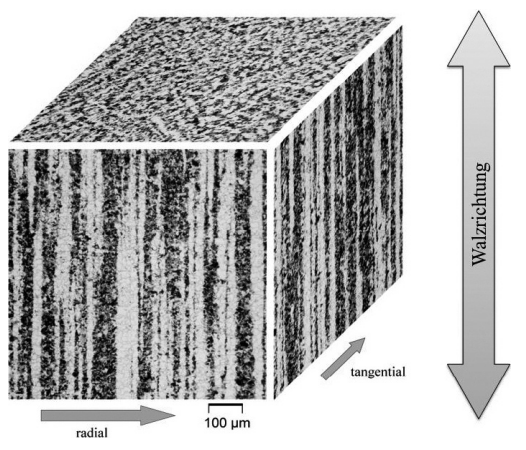

Fig. 3. Segregation structures parallel and perpendicular to the rolling direction $(20 \mathrm{MnCr} 5)$ [27]

Bild 3. Seigerungsstrukturen parallel und senkrecht zur Walzrichtung $(20 \mathrm{MnCr5})$ [27]
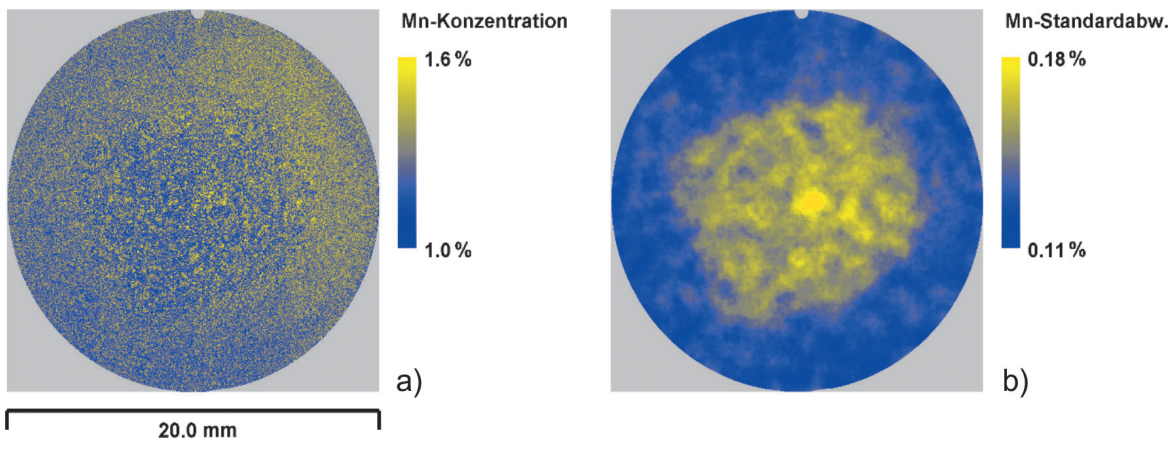

Fig. 4. a) Mn measured values of a continuously cast and rolled semi-finished $20 \mathrm{MnCr} 5$ bar and b) analysis of the measured values by forming the local standard deviation in the Mn measured values [28]

Bild 4. a) Mn-Messwerte einer stranggegossenen und gewalzten Halbzeugstange $20 \mathrm{MnCr} 5$ und b) Analyse der Messwerte durch Bildung der lokalen Standardabweichung in den Mn-Messwerten [28] 
ular to the rolling direction (radial, tangential) show the pronounced banded microstructure, while no banded microstructure is visible in the plane perpendicular to the rolling direction. Macrosegregations, on the other hand, are often observable perpendicular to the rolling direction (see Fig. 4). The evaluation of segregations by means of a microstructure band can only be comparative in the case of identical heat treatment. The cooling rate plays a role: the slower the cooling, the more pronounced is the banded microstructure. In hardened samples, a banded microstructure is often only faintly visible. In purely martensitic specimens, a banded microstructure is often difficult to detect due to small differences in etching behaviour.

Since segregations are spatially distributed chemical inhomogeneities, the application of electron probe microanalysis (EPMA) is the means of choice to characterise segregations [17]. The primary electron beam excites a characteristic X-ray radiation of the material, which can be used to determine the element distribution. Due to the method, the minimum lateral measurement resolution is about $1 \mu \mathrm{m}$. The characterisation of segregations requires a good signal-to-noise ratio, as differences in the order of 0.1$0.5 \mathrm{Ma}$. $\%$ have to be detected. Figure $4 \mathrm{a}$ shows the Mn distribution in a continuously cast billet of a $20 \mathrm{MnCr} 5$ transverse to the rolling direction as determined by EPMA [28]. This measurement data was further analysed by determining the local standard deviation in the Mn values (Figure 4b) [28]. This standard deviation was calculated over the Mn values within an area of $1 \mathrm{~mm}$ diameter and is a measure for the effective distribution coefficient (Equation (1)). Although a rectangular continuous casting was rolled onto a round semi-finished product with a high logarithmic degree of deformation of 4.9 , a slightly off-centre rectangle results for both representations in the inner area. The outer area shows a more homogeneous structure with a lower Mn standard deviation while the inner area of the rectangle shows a coarser structure with a larger Mn standard deviation. The outer, dendritic area and the inner, globulitic area can be clearly distinguished. The area of the equiaxed crystals could not be analysed because it was removed during the turning of the rolling skin.

In hardened $100 \mathrm{Cr} 6$, carbide bands are often found regardless of the austenitising condition, see Figure 5. EPMA can be used to
Walzrichtung [27]. Die beiden Richtungen senkrecht zur Walzrichtung (radial, tangential) zeigen das ausgeprägte zeilige Gefüge, während in der Ebene senkrecht zur Walzrichtung kein zeiliges Gefüge zu erkennen ist. Makroseigerungen sind dagegen oft senkrecht zur Walzrichtung beobachtbar (s. Bild 4). Die Bewertung von Seigerungen über eine Gefügezeiligkeit kann bei identischer Wärmebehandlung nur vergleichend sein. Dabei spielt die Abkühlgeschwindigkeit eine Rolle: je langsamer die Abkühlung erfolgt, desto ausgeprägter ist die Zeiligkeit. In gehärteten Proben ist eine zeilige Struktur oft nur schwach sichtbar. Bei rein martensitischen Proben ist eine Zeiligkeit aufgrund geringer Unterschiede im Anätzverhalten oft schwer nachzuweisen.

Da Seigerungen räumlich verteilte chemische Inhomogenitäten sind, ist die Anwendung der Elektronenstrahl-Mikroanalyse (ESMA) Mittel der Wahl, um Seigerungen zu charakterisieren [17]. Der primäre Elektronenstrahl regt eine charakteristische Röntgenstrahlung des Materials an, anhand derer die Elementverteilung bestimmt werden kann. Methodenbedingt beträgt die minimale laterale Messauflösung etwa $1 \mu \mathrm{m}$. Die Charakterisierung von Seigerungen verlangt ein gutes Signal/Rausch-Verhältnis, da Unterschiede in der Größenordnung 0,1-0,5 Ma.\% detektiert werden müssen. Bild 4a zeigt die mittels ESMA bestimmte Mn-Verteilung in einem stranggegossenen Walzknüppel eines $20 \mathrm{MnCr} 5$ quer zur Walzrichtung [28]. Diese Messdaten wurden weiter analysiert, indem die lokalen Standardabweichung in den Mn-Messwerten bestimmt wurde (Bild 4b) [28]. Diese Standardabweichung wurde jeweils über die Mn-Messwerte innerhalb einer Fläche von $1 \mathrm{~mm}$ Durchmesser gebildet und ist hierbei ein Maß für den effektiven Verteilungskoeffizienten (Gleichung (1)). Obwohl hier von einem Rechteckstrangguss auf ein rundes Halbzeug mit einem hohen logarithmischen Umformgrad von 4,9 gewalzt wurde, ergibt sich für beide Darstellungen im inneren Bereich ein leicht außermittig verschobenes Rechteck. Der äußere Bereich zeigt eine homogenere Struktur mit einer niedrigeren Mn-Standardabweichung, während der innere Bereich des Rechtecks eine gröbere Struktur mit einer größeren MnStandardabweichung zeigt. Es kann klar der äußere, dendritische Bereich und der innere, globulitische Bereich unterschieden werden. Der Bereich der Stängelkristalle konnte nicht analysiert werden, da er beim Abdrehen der Walzhaut entfernt wurde.

In gehärtetem 100Cr6 finden sich unabhängig von der Austenitisierbedingung oft Karbidzeilen, s. Bild 5. Mit der ESMA lässt sich

Fig. 5. Chromium-rich carbide bands in hardened $100 \mathrm{Cr} 6$

a) metallographic micrograph (Nital etching) and

b) microprobe measurement of $\mathrm{Cr}$

Bild 5. Chromreiche Karbidzeilen in gehärtetem $100 \mathrm{Cr} 6$

a) metallographische Mikroaufnahme (Nital-Ätzung) und

b) Mikrosondenmessung von $\mathrm{Cr}$
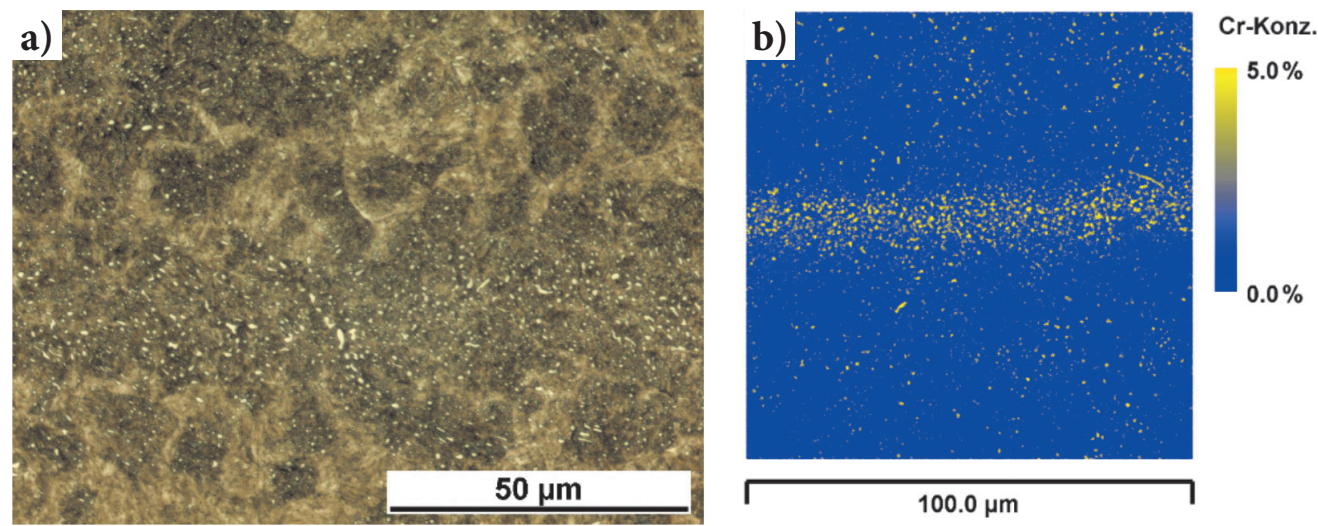

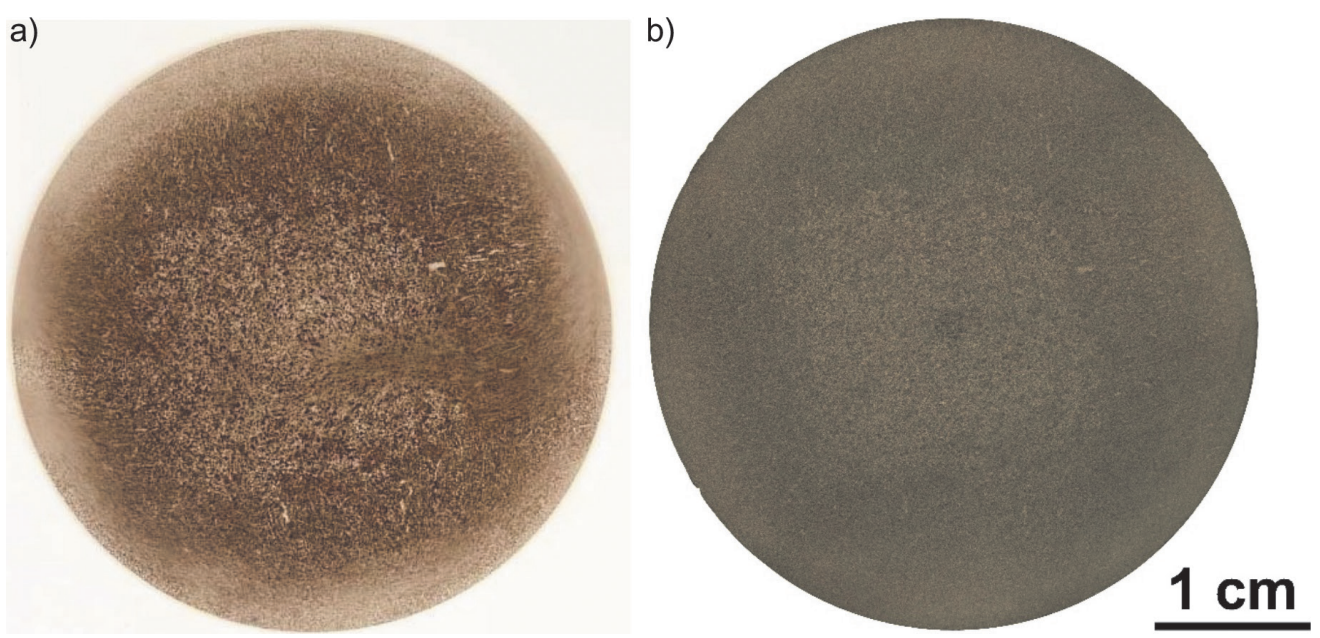

Fig. 6. a) Baumann imprint and b) macrograph on the same transverse section of a $20 \mathrm{MnCr} 5$ semi-finished bar

Bild 6. a) Baumannabdruck und b) Makroaufnahme am selben Querschliff von einer Halbzeugstange $20 \mathrm{MnCr} 5$

prove that these are Cr-rich carbides. These are carbides that are formed during solidification by enriching the melt with carbon and carbide-forming elements and are stable at the usual austenitising temperatures and therefore remain undissolved [29]. This is why these carbide bands are particularly noticeable in hardened $100 \mathrm{Cr} 6$, whereas they are hardly detectable metallographically in a spheroidised-annealed microstructure.

A classical method for the macroscopic characterisation of sulphur segregations is the Baumann imprint [30]. A photographic paper soaked in sulphuric acid is placed on the steel surface, whereupon a reaction occurs between the photographic paper and the steel. The sulphur-rich areas are then darkened on the photographic paper. Since sulphur segregates in parallel with alloying elements such as $\mathrm{Mn}$, macrosegregations and segregation lines can be well characterised in the presence of sulphur segregations. Figure 6 shows a direct comparison of a Baumann imprint with a macrograph on the same transverse section of a semi-finished $20 \mathrm{MnCr} 5$ bar.

Analogously, phosphorus segregations can be made visible with the etchants according to Oberhoffer [31]. Phosphorus segregates similarly to sulphur and thus micro and macrosegregations can be made visible. The etchant forms a thin copper layer on phosphorus-rich areas, which protects them from etching attack. The low-phosphorus areas are thus more strongly etched.

\section{Formation of segregation during primary shaping}

Two fundamental, interconnected phenomena must be taken into account in the formation of segregation [32]. On the one hand, partitioning processes occur thermodynamically during the solidification of multi-component, non-eutectic alloys. On the other hand, the morphology must be considered during solidification. In addition, there are thermal, electrical and electromagnetic flow effects that can have a favourable or unfavourable effect on segregation formation [33, 34]. Morphology and segregation depend not only on the chemical composition but also on the degree of nachweisen, dass es sich hierbei um Cr-reiche Karbide handelt. Diese sind Karbide, die bei der Erstarrung durch Anreicherung der Schmelze mit Kohlenstoff und karbidbildenden Elementen entstehen und bei den üblichen Austenitisiertemperaturen stabil sind und deshalb unaufgelöst bleiben [29]. Deshalb fallen diese Karbidzeilen auch besonders in gehärteten $100 \mathrm{Cr} 6$ auf, während sie in einem GKZ-Gefüge metallographisch kaum nachweisbar sind.

Ein klassisches Verfahren zur makroskopischen Charakterisierung von Schwefel-Seigerungen ist der Baumann-Abdruck [30]. Ein mit Schwefelsäure getränktes Fotopapier wird auf die Stahloberfläche gelegt, worauf zwischen Fotopapier und Stahl eine Reaktion eintritt. Die schwefelreichen Bereiche bilden sich dann dunkel auf dem Fotopapier ab. Da Schwefel parallel zu Legierungselementen wie Mn seigert, lassen sich Makroseigerungen und Seigerungslinien bei Vorliegen von Schwefelseigerungen gut charakterisieren. Bild 6 zeigt einen direkten Vergleich eines Baumannabdrucks mit einer Makroaufnahme am selben Querschliff einer Halbzeugstange 20MnCr5.

Analog lassen sich Phosphorseigerungen mit den Ätzmitteln nach Oberhoffer sichtbar machen [31]. Phosphor seigert ähnlich wie Schwefel und so lassen sich Mikro- und Makroseigerungen sichtbar machen. Das Ätzmittel bildet eine dünne Kupferschicht auf phosphorreichen Bereichen, die diese vor einem Ätzangriff schützt. Die phosphorarmen Bereiche werden somit stärker angeätzt.

\section{Seigerungsentstehung beim Urformen}

Bei der Entstehung der Seigerungen sind zwei grundsätzliche, miteinander gekoppelte Phänomene zu berücksichtigen [32]. Zum einen kommt es bei der Erstarrung von mehrkomponentigen, nichteutektischen Legierungen thermodynamisch bedingt zu Entmischungsvorgängen. Zum anderen ist die Morphologie bei der Erstarrung zu betrachten. Hinzu kommen noch thermisch, elektrisch und elektromagnetisch bedingte Strömungseffekte, die sich günstig oder ungünstig auf die Seigerungsbildung wirken können [33, 34]. Morphologie und Entmischung hängen neben der chemischen Zusam- 
Fig. 7. Schematic representation of the processes during solidification a) partitioning b) transition from plane front to dendritic growth

Bild 7. Schematische Darstellung derVorgänge beim Erstarren a) Entmischung b) Übergang von ebener Front zu dendritischem Wachstum
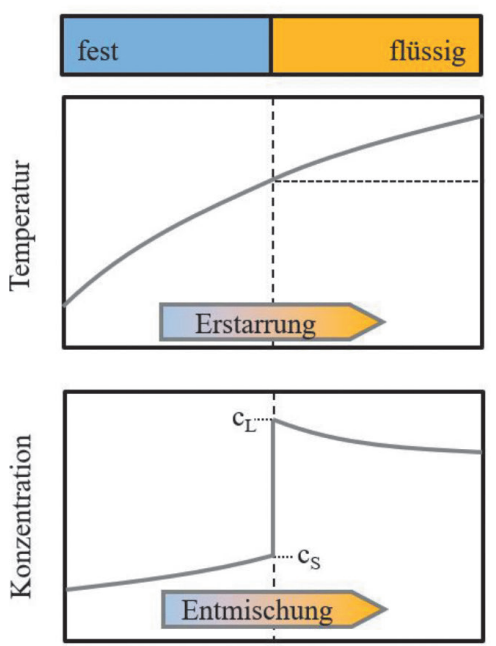

a) Entfernung von der Oberfläche
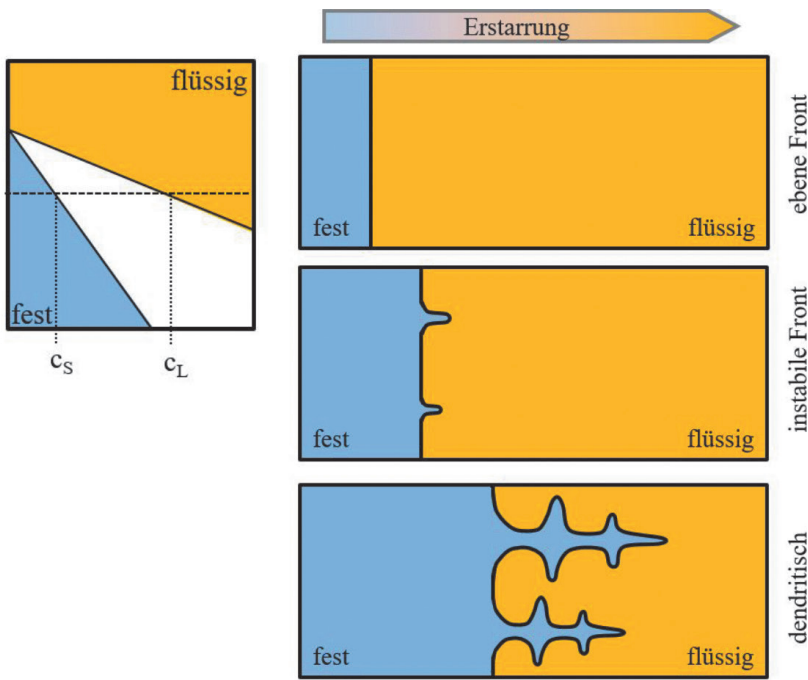

b) Entfernung von der Oberfläche supercooling, the gradients of the temperature and the chemical elements as well as the flow conditions. Somewhat simplified, for most steels, liquidus and solidus temperature decrease with increasing alloy content up to the eutectic point. Thus, during solidification, the residual melt accumulates with the alloying elements, see Figure 7a. Solidification begins at the surface of the ingot or in the strand shell of the continuous casting [15]. Due to the high temperature gradient, the solidification front is initially flat. In the peripheral area, solidification proceeds after a thin globulitic zone in the form of directional equiaxed crystals. However, the solidification front is morphologically unstable and dendritic solidification occurs, as shown schematically in Figure $7 \mathrm{~b}$. The microsegregations result from the concentration fluctuations between the individual dendrites or their arms [13]. Since the dendrites solidify earlier than the region between the dendrites, their concentration of positively segregating alloying elements is lower. At the same time, the residual melt accumulates with increasing solidification. These long-range fluctuations in concentration lead to the macrosegregations.

The macrosegregations can be reduced by keeping the superheating of the melt as low as possible and by intensive cooling in the upper area during continuous casting [11]. In industrial continuous casting, electromagnetic stirring is also used $[11,33,35]$. The aim of this is to homogenise the melt and in particular to reduce core segregation [36]. At the same time, the tips of the dendrites are cut off, which in turn can serve as nuclei for globulitic solidification [37]. Globulites also differ in alloy content from the surrounding residual melt. These globulites sink due to gravity and form an inner, globulitic region [12]. Despite electromagnetic stirring, core segregation occurs that is more enriched with alloying elements compared to the peripheral region. The core segregation is intensified by a subsequent flow of enriched melt into the cavities caused by the shrinkage in the area of the final solidification. Industrially, a reduction of core segregation is achieved by the use of soft reduction, in which these cavities are closed by rolling the mensetzung vom Grad der Unterkühlung, von den Gradienten der Temperatur und der chemischen Elementen sowie den Strömungsbedingungen ab. Etwas vereinfacht nehmen für die meisten Stähle Liquidus- und Solidustemperatur mit zunehmenden Legierungsgehalt bis zum eutektischen Punkt ab. Damit reichert sich bei der Erstarrung die Restschmelze mit den Legierungselementen an, siehe Bild 7a. Die Erstarrung beginnt an der Oberfläche des Block- oder in der Strangschale des Stranggusses [15]. Aufgrund des hohen Temperaturgradienten ist die Erstarrungsfront zunächst eben. Im Randbereich verläuft die Erstarrung nach einer dünnen globulitischen Zone in Form gerichteter Stängelkristalle. Die Erstarrungsfront ist allerdings morphologisch instabil und es kommt zu einer dendritrischen Erstarrung, wie in Bild 7b schematisch dargestellt ist. Die Mikroseigerungen ergeben sich aus den Konzentrationsschwankungen zwischen den einzelnen Dendriten bzw. ihren Armen [13]. Da die Dendriten früher erstarren als der Bereich zwischen den Dendriten ist ihre Konzentration an positiv seigernden Legierungselementen geringer. Gleichzeitig reichert sich mit zunehmender Erstarrung die Restschmelze an. Diese langreichweitigen Konzentrationsschwankungen führen zu den Makroseigerungen.

Die Makroseigerungen lassen sich durch eine möglichst niedrige Überhitzung der Schmelze und durch eine intensive Kühlung im oberen Bereich beim Strangguss reduzieren [11]. Im industriellen Strangguss wird zusätzlich ein elektromagnetisches Rühren angewendet $[11,33,35]$. Dieses hat zum Ziel, die Schmelze zu homogenisieren und insbesondere die Kernseigerung zu verringern [36]. Dabei werden gleichzeitig die Spitzen der Dendriten abgeschlagen, die wiederum als Keime für eine globulitische Erstarrung dienen können [37]. Auch die Globuliten unterscheiden sich im Legierungsgehalt von der umgebenden Restschmelze. Diese Globulite sinken schwerkraftbedingt ab und bilden einen inneren, globulitischen Bereich [12]. Trotz des elektromagnetischen Rührens kommt es zu einer im Vergleich zum Randbereich stärker mit Legierungselementen angereicherten Kernseigerung. Die Kernseigerung wird durch ein Nachfließen von angereicherter Schmelze in die durch die Schrumpfung bedingte Hohlräume im Bereich der 
strand in the area of the final solidification, thus preventing the postflow of the enriched melt [38-40].

While continuous casting shows hardly any differences in the segregation characteristics due to the continuous process in the longitudinal direction, ingot casting results in a spatially more complex segregation formation due to the discontinuous process [10, 41, 42]. In ingot casting, solidification takes place not only from the outside to the inside but also preferentially from the bottom to the top. Therefore, a strongly positively segregated zone occurs in the top area, which solidifies last [41]. This is contrasted by a negatively segregated zone in the bottom region, because freely moving, undirected dendrites sink there due to gravity. A- and V-segregations occur in the middle to upper region [43]. A-segregations occur due to convection of enriched melt, which leads to channel formation. V-segregations occur in the ingot core and is due to shrinkage during solidification as in continuous casting. The segregation and the morphology of the microsegregations in ingot and continuous casting are described by Equations (1) and (2).

\section{Possibilities of reducing segregation after the primary shaping}

In order to improve the properties, it is sometimes necessary to reduce the negative influence of segregation. An obvious solution is to use powder metallurgical and hot isostatical pressed or spray formed material with low segregation [44]. However, this is associated with considerable costs. It is usually more cost-effective to subsequently reduce the degree of segregation from continuous casting.

One way of greatly reducing segregation after the primary shaping is to use remelting processes such as electro-slag remelting (ESR) $[45,46]$ or vacuum arc remelting (VAR) $[47,48]$. In both processes, a narrow melt zone moves axially from bottom to top through the ingot. Due to a constant, axial solidification, segregation of the melt is largely prevented and a material with low micro and macrosegregation is produced. In electroslag remelting, the electrode is continuously melted in a liquid slag that is resistance-heated by an electric current and solidifies underneath as a new ingot. At the same time, the steel can be cleaned of unwanted accompanying elements such as $S$ by means of a reactive slag. In addition, larger non-metallic inclusions in the slag are separated. In vacuum arc remelting, a moving arc between the melting electrode and the resolidified ingot serves as the heat source. With this process, mainly easily vaporised elements and dissolved gases can be removed from the ingot.

Without melting, microsegregations in a diffusion annealing can only be significantly reduced by very long annealing times at high
Enderstarrung verstärkt. Industriell wird eine Reduzierung der Kernseigerung durch den Einsatz von Soft Reduction erreicht, bei der diese Hohlräume durch ein Walzen des Stranges im Bereich der Enderstarrung geschlossen werden und damit das Nachfließen der angereicherten Schmelze verhindert wird [38-40].

Während der Strangguss aufgrund des kontinuierlichen Prozesses in Längsrichtung kaum Unterschiede in der Seigerungscharakteristik aufweist, kommt es beim Blockguss aufgrund des diskontinuierlichen Prozesses zu einer räumlich komplexeren Seigerungsausbildung [10, 41, 42]. Im Blockguss findet die Erstarrung nicht nur von außen nach innen, sondern auch bevorzugt von unten nach oben statt. Deshalb kommt es im Kopfbereich, der zuletzt erstarrt, zu einer stark positiv geseigerten Zone [41]. Dem steht eine negativ geseigerte Zone im Fußbereich gegenüber, weil frei bewegliche, ungerichtete Dendriten schwerkraftbedingt dorthin absinken. Im mittleren bis oberen Bereich kommt es zu A- und V-Seigerungen [43]. A-Seigerungen entstehen durch die Konvektion angereichter Schmelze, die zu einer Kanalbildung führt. V-Seigerungen treten im Blockkern auf und beruhen auf der Schrumpfung beim Erstarren wie beim Strangguss. Die Entmischung und die Morphologie der Mikroseigerungen in Block- und Strangguss werden durch die Gleichungen (1) und (2) beschrieben.

\section{Möglichkeiten der Reduzierung von Seigerungen nach dem Urformen}

Zur Verbesserung der Eigenschaften wird es manchmal notwendig, einen negativen Einfluss von Seigerungen zu reduzieren. Naheliegend ist, auf seigerungsarm hergestelltes pulvermetallurgisches und heißisostatisch gepresstes oder sprühkompaktiertes Material zurückzugreifen [44]. Allerdings ist das mit erheblichen Kosten verbunden. Kostengünstiger ist es meist, den Seigerungsgrad vom Strangguss nachträglich zu verringern.

Eine Möglichkeit, Seigerungen nach dem Urformen stark zu reduzieren, sind Umschmelzverfahren wie das Elektro-SchlackeUmschmelzen (ESU) $[45,46]$ oder das Vakuumlichtbogen-Umschmelzen (VAR) [47, 48]. Bei beiden Verfahren wandert eine schmale Schmelzzone axial von unten nach oben durch den Block. Durch eine konstante, axiale Erstarrung wird eine Entmischung der Schmelze weitestgehend verhindert und es entsteht ein mikround makro-seigerungsarmes Material. Beim Elektro-SchlackeUmschmelzen wird die Elektrode in einer durch elektrischen Strom widerstandserwärmten flüssigen Schlacke kontinuierlich abgeschmolzen und erstarrt darunter als neuer Block. Durch eine reaktive Schlacke kann der Stahl gleichzeitig von unerwünschten Begleitelementen wie S gereinigt werden. Zusätzlich werden v. a. größere nichtmetallische Einschlüsse in der Schlacke abgeschieden. Beim Vakuumlichtbogen-Umschmelzen dient ein wandernder Lichtbogen zwischen der abschmelzenden Elektrode und dem wiedererstarrten Block als Wärmequelle. Bei diesem Verfahren können vor allem leicht verdampfende Elemente und gelöste Gase aus dem Block entfernt werden.

Ohne Aufschmelzen lassen sich Mikroseigerungen bei einem Diffusionsglühen nur durch sehr lange Glühzeiten bei hohen Tem- 
temperatures [49]. The times and temperatures used in industrial practice during the forming processes and during heat treatment are far from sufficient to completely remove segregation structures. Microsegregation in a case-hardened steel is only largely reduced at a diffusion annealing of, for example, $1200{ }^{\circ} \mathrm{C}$ for $24 \mathrm{~h} \mathrm{[50].} \mathrm{Mac-}$ rosegregations, on the other hand, are only slightly affected. It should not be forgotten that diffusion annealing produces coarse grain, which subsequently requires grain refinement. Diffusion annealing before a hot forming step is therefore advantageous. Hot forming produces a fine-grained microstructure again. In contrast, carbide bands, especially in high-alloy steels, can be very stable and cannot be effectively removed by diffusion annealing [4].

\section{Segregation deformation during forming}

\subsection{Hot forming - bar rolling}

Against the background of the elimination of closed porosities as a result of shrinkage during the solidification process and in order to improve the mechanical properties, a minimum forming ratio of $4: 1$ to $8: 1$ is required depending on the intended use [11]. For this reason and to generally reduce the cross-section, the continuously cast billets are already rolled into bars in the desired dimensions at the steelworks. The continuously cast billets often have a rectangular cross-section, but the industry demands round bars. During rolling, therefore, not only is the cross-section reduced, but at the same time the cross-sectional shape is changed from rectangular to round. Due to the reduction in cross-section, the billet is greatly stretched. This applies to the same extent to the microsegregations. These experience a reduction in cross-section and are compressed, i. e. the dendrite arm spacing (Equation 2)) is reduced. At the same time, they are greatly elongated in the direction of rolling, resulting in the often observed banded or fibrous microstructure [51]. As a result, microsegregations can no longer be observed perpendicular to the rolling direction, but only parallel to it, see Figure 3. Bar rolling does not lead to a homogenisation of the segregations, even at a high degree of deformation, but mainly to a strong elongation in the rolling direction.

The situation is different with the macrosegregations, which show up very well perpendicular to the rolling direction both in the macrograph (Figure 8) and in the element distribution (Figure 4). Figure 8 shows the effect of macrosegregation perpendicular to the rolling direction (transverse section) and the corresponding microsegregation parallel to the rolling direction (longitudinal section) after bar rolling on the basis of metallographic sections of $20 \mathrm{MnCr} 5$. Here, too, the inner globulitic and the outer dendritic areas are clearly visible in the transverse section. The core segregation is also clearly visible. In the longitudinal section it is visible that the outer, dendritic area forms a clearly less pronounced lenticularity than the inner, globulitic area. The structure of the segregations and the width of the distribution in the Mn content is peraturen deutlich reduzieren [49]. Die in der industriellen Praxis verwendeten Zeiten und Temperaturen bei den Umformvorgängen und während der Wärmebehandlung sind bei Weitem nicht ausreichend, um Seigerungsstrukturen komplett abzubauen. Erst bei einem Diffusionsglühen von bspw. $1200^{\circ} \mathrm{C}$ für $24 \mathrm{~h}$ bauen sich Mikroseigerung in einem Einsatzstahl weitestgehend ab [50]. Makroseigerungen werden dagegen nur geringfügig beeinflusst. Nicht vergessen werden darf, dass durch die Diffusionsglühung Grobkorn entsteht, das hinterher wieder einer Kornfeinung bedarf. Vorteilhaft ist deshalb ein Diffusionsglühen vor einem Warmumformschritt. Durch das Warmumformen entsteht wieder ein feinkörniges Gefüge. Karbidzeilen - vor allem in hochlegierten Stählen - können dagegen sehr stabil sein und lassen sich durch ein Diffusionsglühen nicht effektiv abbauen [4].

\section{Seigerungsverformung beim Umformen}

\subsection{Warmumformen - Stabstahlwalzen}

Vor dem Hintergrund der Beseitigung von geschlossenen Porositäten in Folge der Schwindung während des Erstarrungsvorgangs und zur Verbesserung der mechanischen Eigenschaften wird eine Mindestumformgrad 4:1 bis 8:1 in Abhängigkeit des Einsatzzweckes gefordert [11]. Aus diesem Grund und zur allgemeinen Reduzierung des Querschnittes werden die stranggegossenen Knüppel bereits im Stahlwerk zu Stäben in den gewünschten Abmaßen gewalzt. Oft liegen die stranggegossenen Knüppel mit rechteckigem Querschnitt vor, aus der Industrie werden aber Rundstäbe gefordert. Während des Walzens wird daher nicht nur der Querschnitt reduziert, sondern gleichzeitig die Querschnittsform von rechteckig auf rund geändert. Durch die Querschnittsreduzierung wird der Knüppel stark gestreckt. Das gilt in gleichem Maße für die Mikroseigerungen. Diese erfahren eine Querschnittsreduzierung und werden verdichtet, d. h. der Dendritenarmabstand (Gleichung (2)) wird verringert. Gleichzeitig werden sie in Walzrichtung stark gelängt, wodurch die oft beobachtete zeilige oder faserige Struktur entsteht [51]. Resultierend lassen sich Mikroseigerungen nicht mehr senkrecht zur Walzrichtung beobachten, sondern nur parallel dazu, s. Bild 3. Ein Stabstahlwalzen führt auch bei hohem Umformgrad nicht zu einer Homogenisierung der Seigerungen, sondern vornehmlich zu einer starken Längung in Walzrichtung.

Anders verhält es sich mit der Makroseigerungen, die sich sowohl im Makroschliff (Bild 8) als auch in der Elementverteilung (Bild 4) sehr gut senkrecht zur Walzrichtung zeigen. Bild 8 zeigt anhand metallographischer Schliffe an $20 \mathrm{MnCr} 5$ den Effekt der Makroseigerung senkrecht zur Walzrichtung (Querschliff) und die korrespondierenden Mikroseigerungen parallel zur Walzrichtung (Längsschliff) nach dem Stabstahlwalzen. Auch hier ist deutlich der innere, globulitische und der äußere, dendritische Bereich im Querschliff ausmachbar. Auch die Kernseigerung ist klar erkennbar. Im Längsschliff ist sichtbar, dass der äußere, dendritischer Bereich eine deutlich geringer ausgeprägte Zeiligkeit ausbildet als der innere, globulitische Bereich. Die Struktur der Seigerungen und die Breite der Verteilung im Mn-Gehalt ist im 


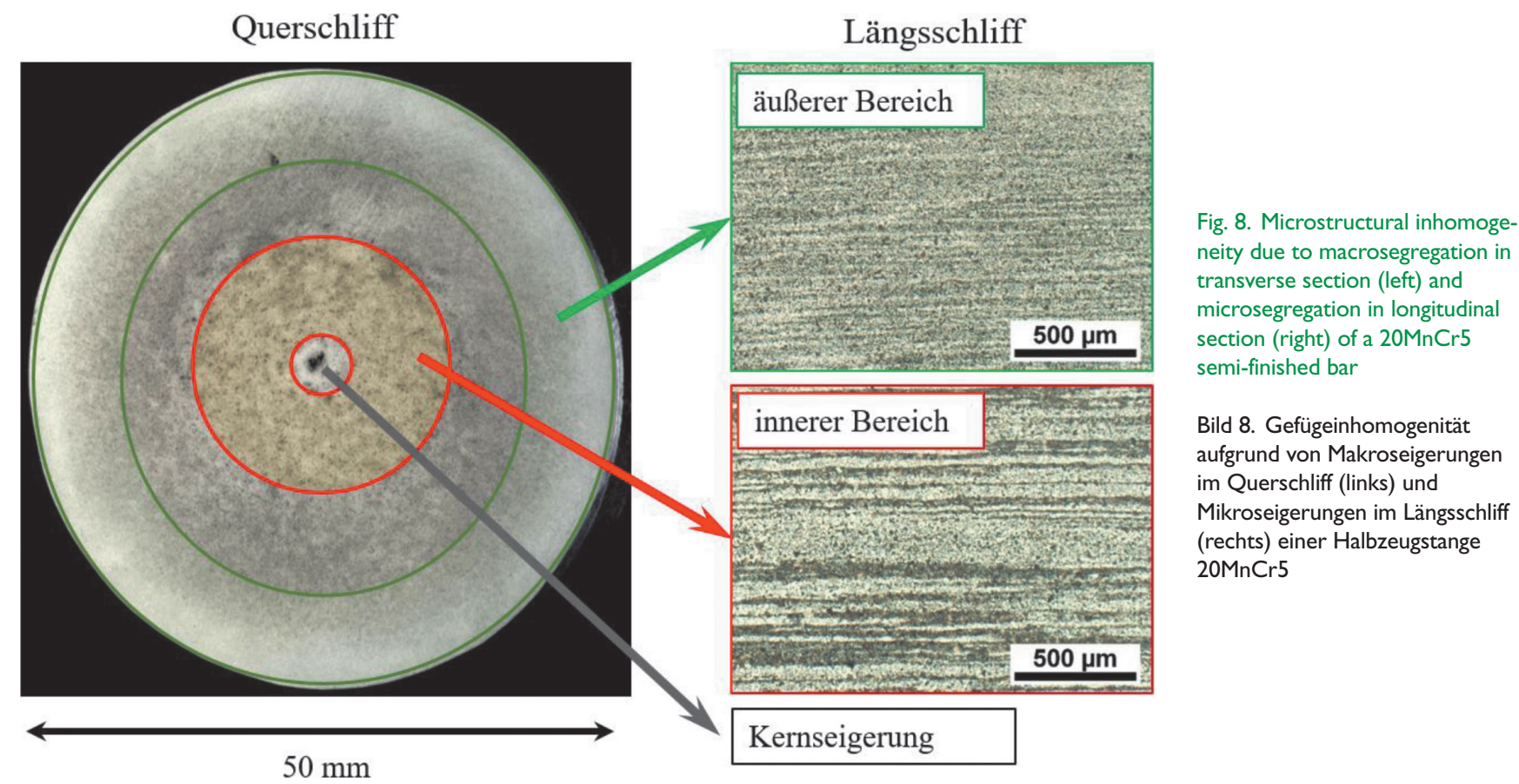

greater in the globulitic area than in the dendritic area [28]. Both lead to the more pronounced tickness in the inner region visible in Figure 8.

During cooling after bar rolling or hot forming, transformations occur that are influenced by the segregations. Since the basic processes do not differ from the transformations during heat treatment, please refer to Chapter 7. The ferrite-pearlite or spheroidized-annealing treatments frequently carried out after rolling or forging are also dealt with there.

\subsection{Hot forming - (die) forging}

Die forging is used to turn a semi-finished product section into a blank that is already similar to the component. Just as in bar rolling, the segregations are strongly deformed. In contrast to bar rolling, the segregation lines can be very complex depending on the forming steps. The core area is often punched out in connection with forging. The advantage of this is that the core segregation is largely removed and can no longer cause problems in the final heat treatment. At the same time, the punching leads to a strong deformation in the vicinity of the punching area. As an example, Figure 9 shows a macrograph and the corresponding Mn distribution on a forging blank for a simple gear made of 20MnCr5 (after [52]). Due to the punching, the segregation lines hit the surface almost perpendicularly (on the right in Figure 9a and b respectively). Both in the macrograph and in the corresponding Mn distribution, the fine dendritic and the coarse globulitic areas can be distinguished. Even with this relatively simple geometry, forging leads to a complex distribution of segregations. In components with strong changes in cross-section, the segregations can therefore be formed locally in very different ways. globulitischen Bereich größer als im dendritischen Bereich [28]. Beides führt zu der in Bild 8 sichtbaren, ausgeprägteren Zeiligkeit im inneren Bereich.

Beim Abkühlen nach dem Stabstahlwalzen oder einer Warmumformung kommt es zu Umwandlungen, die von den Seigerungen beeinflusst werden. Da sich die prinzipiellen Vorgänge nicht von den Umwandlungen bei der Wärmebehandlung unterscheiden, sei dazu auf Kapitel 7 verwiesen. Auch die im Anschluss an das Walzen oder Schmieden häufig durchgeführten FP- oder GKZ-Glühbehandlungen werden dort behandelt.

\subsection{Warmumformen - (Gesenk-)Schmieden}

Durch Gesenkschmieden wird aus einem Halbzeugabschnitt ein dem Bauteil schon ähnlicher Rohling gemacht. Genau wie beim Stabstahlwalzen werden dabei die Seigerungen stark verformt. Im Unterschied zum Stabstahlwalzen können die Seigerungslinien in Abhängigkeit der Umformschritte sehr komplex ausfallen. Oft wird im Zusammenhang mit dem Schmieden der Kernbereich ausgelocht. Vorteilhaft dabei ist, dass die Kernseigerung größtenteils entfernt wird und diese in der abschließenden Wärmebehandlung keine Probleme mehr bereiten kann. Gleichzeitig führt das Auslochen zu einer starken Verformung in der Nähe des ausgelochten Bereichs. Beispielhaft zeigt Bild 9 eine Makroaufnahme und die zugehörige Mn-Verteilung an einem Schmiederohling für ein einfaches Zahnrad aus 20MnCr5 (nach [52]). Durch das Auslochen stoßen die Seigerungslinien fast senkrecht auf die Oberfläche (jeweils rechts in Bild 9a und b). Sowohl im Makroschliff als auch in der zugehörigen Mn-Verteilung lassen sich die feinen dendritischen und die groben globulitischen Bereiche unterscheiden. Bereits bei dieser relativ einfachen Geometrie führt ein Schmieden zu einem komplexen Verlauf der Seigerungen. Bei Bauteilen 


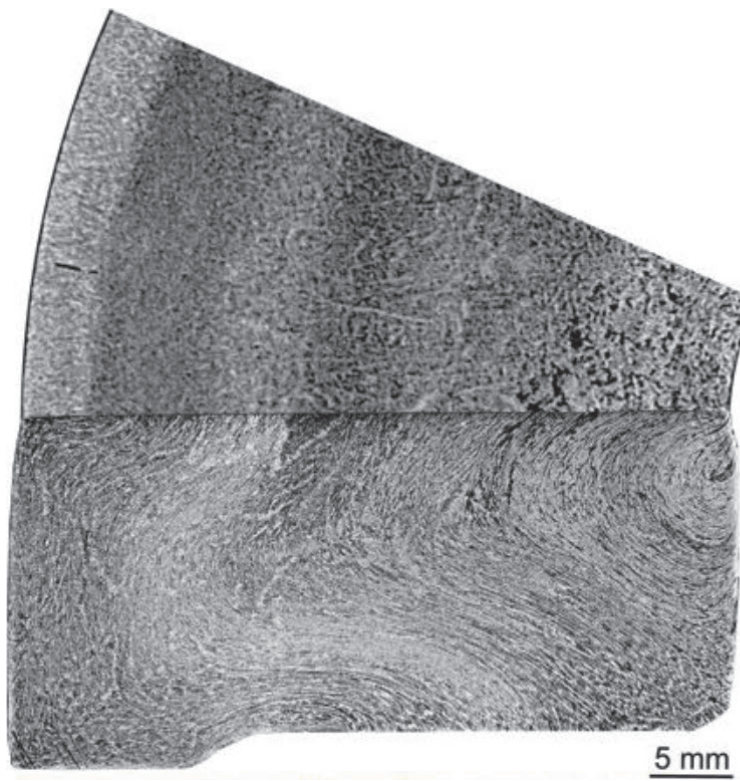

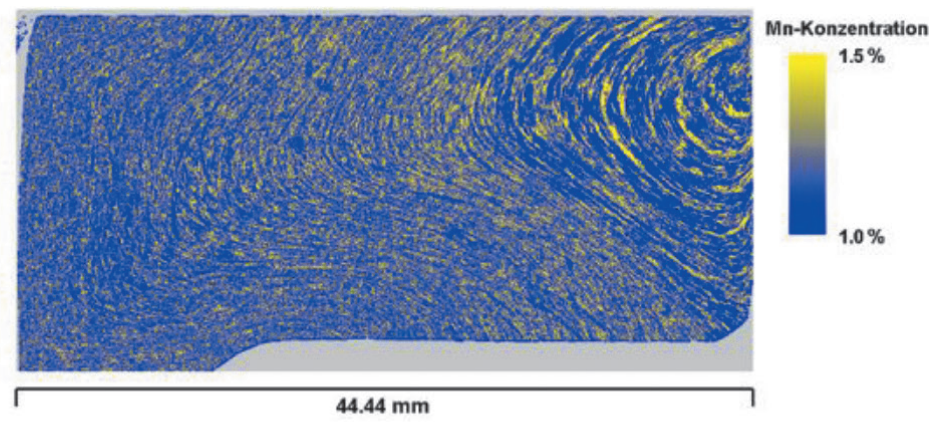

Figure 9. Segregations in the forging blank for a gear made of $20 \mathrm{MnCr} 5$ a) macrograph and b) Mn distribution (after [52])

Bild 9. Seigerungen im Schmiederohling für ein Zahnrad aus $20 \mathrm{MnCr} 5$ a) Makroaufnahme und b) Mn-Verteilung (nach [52])

\subsection{Cold forming - pressing}

During cold forming, no surface scaling occurs as in hot forming. Therefore, cold-formed components can be produced closer to the final shape and machining can be largely dispensed with. Segregation lines are then usually arranged parallel to the surface. However, pronounced segregations can lead to a very inhomogeneous distribution of the austenite grain size, sometimes also to abnormal grain growth, after austenitising $[53,54]$. Abnormal grain growth is discussed in more detail in Chapter 7.4, as this is part of the heat treatment.

A particularly high probability of failure in cold forming occurs when a ferrite/pearlite bands with bainite or martensite bands occurs due to particularly pronounced segregation combined with too rapid cooling. These effects have been studied in particular for multiphase steels such as dual-phase or TRIP steels. However, they can also be transferred to case-hardened or quenched and tempered steels. The then usually very brittle bainite or martensitic bands lack the deformation capacity and these easily fail during forming [55]. For this reason, material with as little segregation as possible is used in AFP steels in particular.

\section{Selection of segregations during machining}

Machining is characterised by a removal of mass, which means that the segregation lines in the component are only changed close to the surface. However, due to the removal of mass, segregations can be cut, which can have a negative effect on the service life, see mit starken Querschnittsänderungen kann es daher lokal zu sehr unterschiedlichen Ausbildung der Seigerungen kommen.

\subsection{Kaltumformen - Pressen}

Während des Kaltumformens tritt keine Oberflächenverzunderung wie beim Warmumformen auf. Deshalb können kaltumgeformte Bauteile endformnaher hergestellt und auf eine Zerspanung weitestgehend verzichtet werden. Seigerungszeilen sind dann meist parallel zur Oberfläche angeordnet. Allerdings kann es bei ausgeprägten Seigerungen zu einer sehr inhomogener Verteilung der Austenitkorngröße, teilweise auch zu abnormalen Kornwachstum, nach einer Austenitisierung kommen [53, 54]. Abnormales Kornwachstum wird in Kapitel 7.4 vertieft, da dies zur Wärmebehandlung gehört.

Eine besonders große Versagenswahrscheinlichkeit beim Kaltumformen tritt auf, wenn eine Ferrit/Perlit-Zeiligkeit mit Bainit- oder Martensitzeilen aufgrund besonders ausgeprägter Seigerungen verbunden mit einer zu schnellen Abkühlung auftritt. Insbesondere bei Mehrphasenstählen wie Dual-Phasen oder TRIP-Stählen wurden diese Effekte untersucht. Sie lassen sich aber auch auf Einsatz- oder Vergütungsstähle übertragen. Den dann meist sehr spröden Bainit- oder Martensitzeilen fehlt das Verformungsvermögen und diese versagen bei Umformung leicht [55]. Insbesondere in AFP-Stählen wird aus diesem Grund möglichst seigerungsarmes Material eingesetzt.

\section{Selektion von Seigerungen beim Zerspanen}

Das Zerspanen ist durch eine Masseabnahme charakterisiert, wodurch die Seigerungslinien im Bauteil allerhöchstens oberflächennah verändert werden. Durch die Masseabnahme können allerdings Seigerungen angeschnitten werden, was sich negativ auf die 


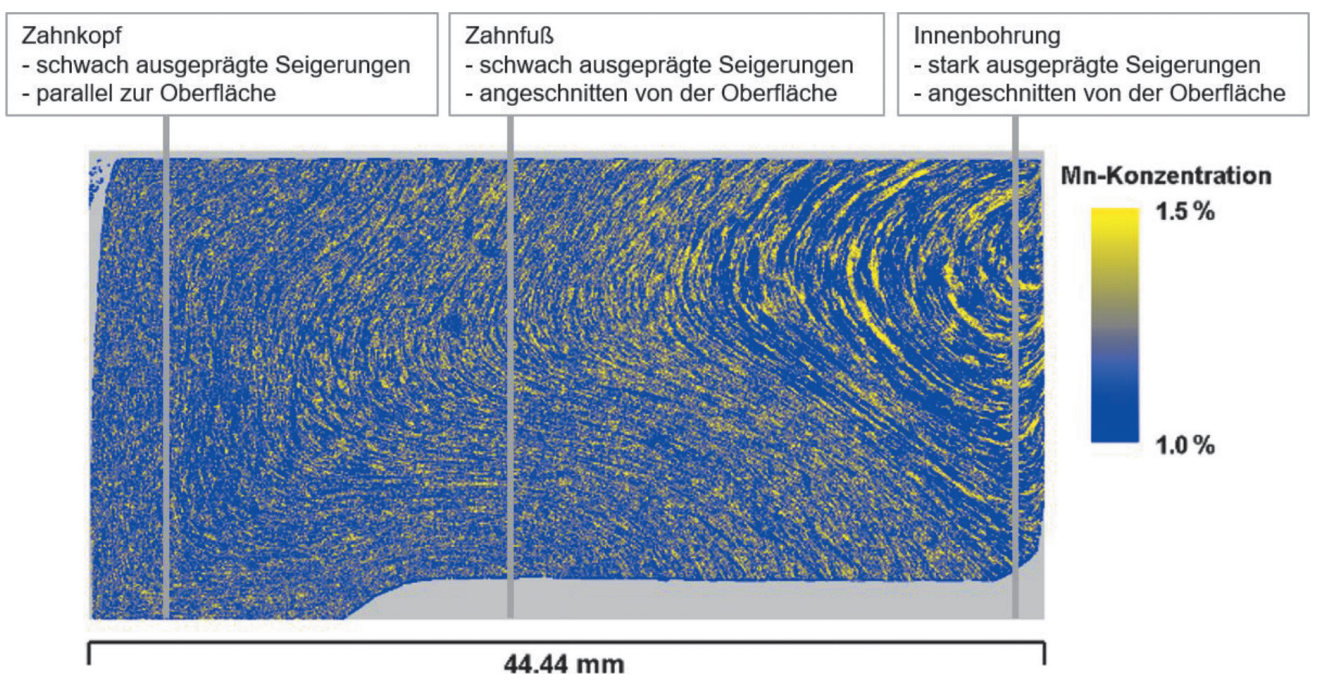

Fig. 10. Cutting the segregations during gear production in the forging blank for a gear made of $20 \mathrm{MnCr} 5$ for the positions tooth tip, tooth root and inner bore

Bild 10. Anschneiden der Seigerungen bei der Zahnradfertigung im Schmiederohling für ein Zahnrad aus $20 \mathrm{MnCr} 5$ für die Positionen Zahnkopf, Zahnfuß und Innenbohrung

Chapter 8. As an example, Figure 10 shows the segregation distribution at characteristic positions for the removal of a gear made of $20 \mathrm{MnCr} 5$ from the forging blank (Figure 9). While in the tooth tip area the segregations run vertically and thus parallel to the surface, they intersect the surface in the area of the tooth root but also in the inner bore. In the tooth tip and root area, the segregations are only slightly pronounced, while the inner bore lies in the area of strongly pronounced segregations.

Hot-formed forged blanks like the one in Figure 9 are produced with a few mm oversize. When turning to final dimension, there is freedom in the height positioning of the component in the semi-finished product. This means that the ratio of the mass removed at the top and the mass removed at the bottom can be varied. This means that the segregation lines are positioned differently in the component. This results in a distortion contribution due to heat treatment that depends on the machining strategy [56]. Conversely, the machining strategy can be designed in such a way that the distortion due to heat treatment is reduced, as explained in Chapter 7.3.

\section{Influence of segregation during heat treatment}

\subsection{Formation of a banded microstructure by microsegregation}

In heat treatment, on the one hand, the effects from a banded initial microstructure, which have an effect especially during heating, have to be discussed. On the other hand, the consequences of chemical inhomogeneity during cooling or quenching must be dealt with. Microstructural transformations are discussed in the following along the process chain. First, the formation of a ferritic/ pearlitic microstructure during slow cooling, e. g. after forging or during ferrite-pearlite annealing, is explained. Then the re-austenitising of the ferritic/pearlitic microstructure is discussed. This is followed by bainite/martensite formation during quenching.
Lebensdauer auswirken kann, s. Kapitel 8. Beispielhaft ist in Bild 10 der Seigerungsverlauf an charakteristischen Positionen für die Entnahme eines Zahnrades aus 20MnCr5 aus dem Schmiederohling (Bild 9) dargestellt. Während im Zahnkopfbereich die Seigerungen senkrecht verlaufen und damit parallel zur Oberfläche, schneiden sie im Bereich des Zahnfußes aber auch in der Innenbohrung die Oberfläche. Im Zahnkopf- und Zahnfußbereich sind die Seigerungen nur schwach ausgeprägt, während die Innenbohrung im Bereich stark ausgeprägter Seigerungen liegt.

Warmumgeformte Schmiederohlinge, wie in Bild 9, werden mit einigen mm Aufmaß gefertigt. Beim Drehen auf Endmaß gibt es Freiheiten in der Höhenpositionierung des Bauteils im Halbzeug. So kann das Verhältnis der oben und der unten abgenommen Masse variiert werden. Dadurch kommen die Seigerungslinien unterschiedlich im Bauteil zu liegen. Dabei ergibt sich ein von der Zerspanstrategie abhängiger Verzugsbeitrag infolge der Wärmebehandlung [56]. Im Umkehrschluss kann u. U. die Zerspanstrategie so gestaltet werden, dass der Verzug infolge der Wärmebehandlung verkleinert wird, wie in Kapitel 7.3 weiter ausgeführt wird.

\section{Einfluss von Seigerungen in der Wärmebehandlung}

\subsection{Ausbildung eines zeiligen Gefüges durch Mikroseigerungen}

Bei der Wärmebehandlung sind zum einen die Effekte aus einem zeiligen Ausgangsgefüge, die sich insbesondere beim Erwärmen auswirken, zu diskutieren. Zum anderen müssen die Folgen aus der chemischen Inhomogenität beim Abkühlen oder Abschrecken behandelt werden. Gefügeumwandlungen werden im Folgenden entlang der Prozesskette diskutiert. Zunächst wird die Entstehung eines ferritisch/ perlitischen Gefüges bei einer langsamen Abkühlung bspw. nach dem Schmieden oder bei einem FP-Glühen erläutert. Anschließend wird die Wiederaustenitisierung des ferritisch/perlitischen Gefüges behandelt. Es folgt die Bainit/Martensitbildung beim Abschrecken. 
As with forming, temperatures and durations during heat treatment are not sufficient to significantly reduce segregation. In contrast, the carbon homogenises during austenitising. An estimation with the diffusion simulator DICTRA [57] showed that in the case-hardening steel $20 \mathrm{MnCr} 5$ at a holding temperature of $940{ }^{\circ} \mathrm{C}$, the carbon is largely homogeneously distributed after a few minutes, even with pronounced segregations. The carbon gradient caused by the difference in activity is less than $0.01 \%$. The homogenisation only applies to the carbon dissolved in the austenite. The diffusion of substitutional alloying elements such as $\mathrm{Cr}$ or $\mathrm{Mn}$ is negligible. Transformations in a banded structure during cooling are therefore essentially due to inhomogeneously distributed substitutionally dissolved alloying elements [2]. In the case of higher carbon bearing or tool steels, carbides, some of which are arranged in rows, can remain undissolved, as is also shown in Figure 5.

The distribution of the substitutional alloying elements has a significant influence on the microstructure formation during cooling, as shown schematically in Figure 11. During slow cooling to achieve a ferrite/pearlite microstructure, ferrite initially nucleates at the former austenite grain boundaries at the positions with the lowest content of elements such as $\mathrm{Mn}$, Ni or $\mathrm{Cr}$, which retard ferrite formation [58]. Due to the row arrangement of these elements, these nuclei appear as if on a string of pearls [27]. These nuclei then grow together and form a continuous band of ferrite. In the process, they displace the carbon in the remaining austenite. These areas already have an increased proportion of alloying elements that retard ferrite formation. The additional carbon further increases the austenite stability. The remaining austenite transforms into pearlite during further cooling. The result is a sharp sequence of ferrite and pearlite bands. In extreme cases, the austenite can be stabilised to such an extent that the pearlite
Wie auch beim Umformen sind bei der Wärmebehandlung Temperaturen und Dauern nicht ausreichend, um Seigerungen signifikant abzubauen. Dagegen homogenisiert der Kohlenstoff beim Austenitisieren. Eine Abschätzung mit dem Diffusionssimulator DICTRA [57] ergab, dass im Einsatzstahl 20MnCr5 bei einer Haltetemperatur von $940{ }^{\circ} \mathrm{C}$ der Kohlenstoff auch bei ausgeprägten Seigerungen nach wenigen Minuten weitestgehend homogen verteilt ist. Der durch den Aktivitätsunterschied bedingte Kohlenstoffgradient liegt unter 0,01\%. Die Homogenisierung gilt nur für den im Austenit gelösten Kohlenstoff. Die Diffusion der substitutionellen Legierungselemente wie Cr oder Mn ist vernachlässigbar klein. Umwandlungen in zeiliger Ausprägung beim Abkühlen sind also im Wesentlichen auf inhomogen verteilte substitutionell gelöste Legierungselemente zurückzuführen [2]. Bei höherkohlenstoffhaltigen Wälzlager- oder Werkstoffstähle können Karbide, die teilweise zeilenweise angeordnet sind, unaufgelöst bleiben, wie auch in Bild 5 dargestellt ist.

Die Verteilung der substitutionellen Legierungselemente hat einen signifikanten Einfluss auf die Gefügeausbildung beim Abkühlen, wie es schematisch in Bild 11 dargestellt ist. Bei einer langsamen Abkühlung zur Erzielung eines Ferrit/Perlit-Gefüges keimt an den ehemaligen Austenitkorngrenzen zunächst der Ferrit an den Positionen mit dem niedrigsten Anteil an Elementen wie Mn, Ni oder Cr, die die die Ferritbildung verzögern, an [58]. Aufgrund der zeiligen Anordnung dieser Elemente erscheinen diese Keime wie an einer Perlenschnur [27]. Diese Keime wachsen dann zusammen und bilden ein durchgängiges Band an Ferrit. Dabei verdrängen sie den Kohlenstoff in den verbleibenden Austenit. Diese Bereiche haben schon einen erhöhten Anteil die Ferritbildung verzögernde Legierungselementen. Durch den zusätzlichen Kohlenstoff kommt es $\mathrm{zu}$ einer weiteren Steigerung der Austenitstabilität. Der noch vorhandene Austenit wandelt bei weiterer Abkühlung in Perlit um. Als Folge ergibt sich eine scharfe

Fig. 11. Schematic representation of the formation of a banded microstructure during cooling

Bild 11. Schematische Darstellung der Bildung einer zeiligen Gefügestruktur beim Abkühlen
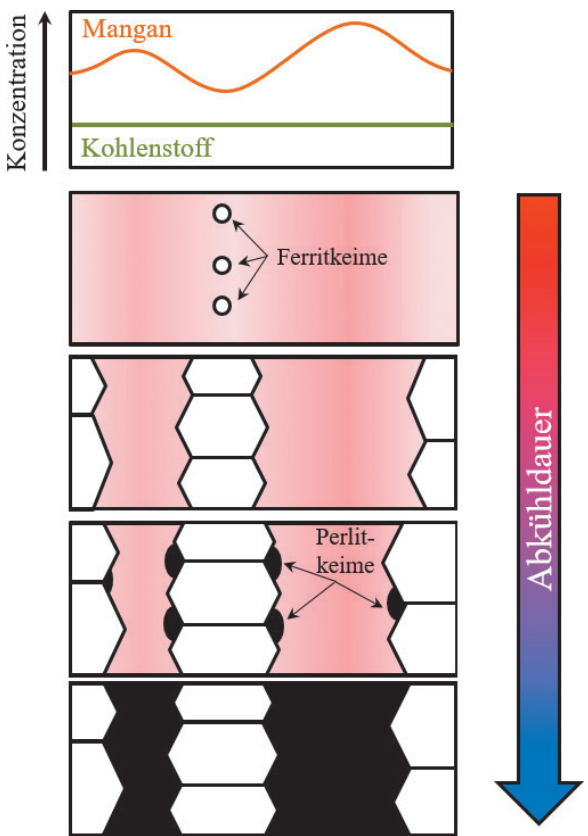
transformation is suppressed and bainite or martensite is formed. Positive segregations can thus lead to bainite or martensite where a ferritic/pearlitic microstructure was expected, negative segregations can correspondingly lead to ferrite/pearlite where bainite or martensite was expected.

With a suitable heat treatment, it is often possible to suppress the formation of the ferritic/perlitic microstructure in row bands during ferrite-pearlite annealing. This is done by rapid cooling to a temperature just above the bainite starting temperature and holding it there until complete transformation [59]. The rapid cooling to a low holding temperature results in relatively uniform formation of ferrite nuclei in all areas due to the high supercooling. This favours a uniform ferrite formation and thus a formation of a banded microstructure is largely prevented. Conversely, it can be concluded that the absence of a banded microstructure does not mean that segregation is absent. In addition to the cooling rate, the formation of a banded microstructure depends on the austenite grain size [60]. The larger the austenite grain size, the coarser the bands. Above a certain austenite grain size, a banded microstructure is no longer found. The cause here is also nucleation, which essentially begins at the austenite grain boundaries.

If a steel with a ferrite/pearlite microstructure is heated up, then the austenite formation begins in the carbon-rich pearlite, as the local Ac1 temperature here is significantly lower than in the low-carbon ferrite [61]. Therefore, if heating is not too fast, the pearlite is completely transformed into austenite before the ferrite transforms. A banded ferrite/pearlite microstructure thus develops into a banded ferrite/austenite microstructure as a transition microstructure. The austenite formed from the pearlite initially has a significantly higher carbon content than the nominal content of the steel. This is reduced after ferrite dissolution by diffusion equalisation during holding at the austenitising temperature. From a microstructural point of view, this is relevant if austenitising is not complete, whether in the core of large components, if the austenitising time is too short, which occurs for example with inductive short-time heating, or in the setting of multiphase microstructures such as with dual-phase steels $[62,63]$. Figure 12 shows the induction-hardened surface layer of a 42CrMo4 with a banded ferritic/pearlitic initial microstructure parallel to the surface. While in the hardened surface layer still isolated remains of the ferrite bands can be observed, which have not dissolved, the pearlite bands are already partially austenitised even at greater depths. At the same time, a banded microstructure is also observed in the martensitic zone, which is probably caused by insufficient homogenisation of the carbon during austenitising.

In conventional heat treatment, the resulting grain size of the austenite is directly influenced by the initial microstructure. Both, nucleation of the austenite and the growth rate of the austenite are decisive. Both, effects are greater in pearlite or martensite than in ferrite, since a long-range carbon diffusion is necessary for a ferrite transformation at the usual heating rates. For example, in
Abfolge von Ferrit- und Perlitbändern. Im Extremfall kann der Austenit soweit stabilisiert sein, dass die Perlitumwandlung unterdrückt wird und es zu einer Bainit- oder Martensitbildung kommt. Positive Seigerungen können also zu Bainit oder Martensit führen, wo ein ferritisch/perlitisches Gefüge erwartet wurde, negative Seigerungen können entsprechend zu Ferrit/Perlit führen, wo Bainit oder Martensit erwartet wurde.

Durch eine geeignete Wärmebehandlung lässt sich oft eine Ausbildung des ferritisch/perlitischen Gefüges in zeiligen Bändern bei der FP-Glühung unterdrücken. Dazu wird schnell auf eine Temperatur knapp oberhalb der Bainitstarttemperatur abgekühlt und dort bis zur vollständigen Umwandlung gehalten [59]. Die schnelle Abkühlung auf eine niedrige Haltetemperatur führt zu einer relativ gleichmäßigen Ausbildung von Ferritkeimen in allen Bereichen aufgrund der hohen Unterkühlung. Dadurch wird eine gleichmäßige Ferritbildung begünstigt und somit wird eine Ausbildung eines zeiligen Gefüges weitestgehend verhindert. Im Umkehrschluss kann gefolgert werden, dass aus einem fehlenden zeiligen Gefüge nicht auf die Abwesenheit von Seigerungen geschlossen werden kann. Neben der Abkühlgeschwindigkeit hängt die Ausbildung einer zeiligen Struktur von der Austenitkorngröße ab [60]. Je größer die Austenitkorngröße, desto gröbere Zeilen finden sich. Ab einer bestimmten Austenitkorngröße findet sich dann kein zeiliges Gefüge mehr. Ursache ist auch hier die Keimbildung, die im Wesentlichen an den Austenitkorngrenzen beginnt.

Wird ein Stahl mit Ferrit/Perlit-Gefüge erwärmt, dann beginnt die Austenitbildung im kohlenstoffreichen Perlit, da hier die lokale Ac1-Temperatur deutlich niedriger als im kohlenstoffarmen Ferrit ist [61]. Bei nicht zu schneller Erwärmung ist deshalb der Perlit vollständig in Austenit umgewandelt, bevor der Ferrit umwandelt. Aus einem zeiligen Ferrit/Perlit-Gefüge entsteht als Übergangsgefüge also ein zeiliges Ferrit/Austenit-Gefüge. Dabei hat der aus dem Perlit gebildete Austenit zunächst einen deutlich erhöhten Kohlenstoffgehalt gegenüber dem nominellen Gehalt des Stahls. Dieser wird nach der Ferritauflösung durch Diffusionsausgleich während des Haltens auf Austenitisiertemperatur abgebaut. Aus Gefügesicht ist das relevant, wenn nicht vollständig austenitisiert wird, sei es im Kern großer Bauteile bei zu kurzer Austenitisierdauer, die beispielsweise bei induktiver Kurzzeiterwärmung auftritt, oder bei der Einstellung von mehrphasigen Gefügen wie bei DualPhasen-Stählen $[62,63]$. Bild 12 zeigt die induktiv gehärtete Randschicht eines 42CrMo4 mit zeiligem ferritisch/perlitischem Ausgangsgefüge parallel zur Oberfläche. Während in der gehärteten Randschicht noch vereinzelte Reste der Ferritzeilen zu beobachten sind, die sich nicht aufgelöst haben, sind die Perlitzeilen auch bei größeren Tiefen schon teilweise austenitisiert. Gleichzeitig beobachtet man auch in der martensitischen Zone eine zeilige Struktur, die vermutlich durch eine unzureichende Homogenisierung des Kohlenstoffs bei der Austenitisierung verursacht wird.

Bei einer konventionellen Wärmebehandlung wird die resultierende Korngröße des Austenits direkt vom Ausgangsgefüge beeinflusst. Dabei sind sowohl Keimbildung des Austenits als auch Wachstumsgeschwindigkeit des Austenits entscheidend. Beide Effekte sind in Perlit oder Martensit größer als im Ferrit, da für eine Ferritumwandlung bei den üblichen Erwärmgeschwindigkeiten 
Fig. 12. Inductively surface hardened $42 \mathrm{CrMo} 4$ with a banded ferritic-pearlitic initial microstructure

Bild 12. Induktiv randschichtgehärteter $42 \mathrm{CrMo} 4 \mathrm{mit}$ zeiligem ferritisch-perlitischem Ausgangsgefüge case-hardened steel $20 \mathrm{MnCr} 5$, an austenite grain size of $\mathrm{G}=10$ was found in the former ferrite bands and of $\mathrm{G}=12$ in the former pearlite bands [64]. In addition to the grain size, the grain shape can also be influenced. For an X2CrNi12, a grain shape clearly elongated in the segregation direction was found [65]. Something similar is found for many multiphase steels such as dual-phase or TRIP steels.

Analogous to slow cooling, the transformation during quenching begins in the areas with a high critical cooling rate [66]. Here, too, the areas with a lower critical cooling rate transform later. The resulting microstructure can be, for example, a banded bainitic/martensitic microstructure. Especially in case-hardened components, a banded bainitic/martensitic microstructure is usually present in the core, as Figure 13 shows with the example of $20 \mathrm{MnCr} 5$. Even with a purely martensitic microstructure, the formation can be banded, as the local martensite starting temperature depends on the segregation-related local chemical composition. These are then noticeable in a mac-

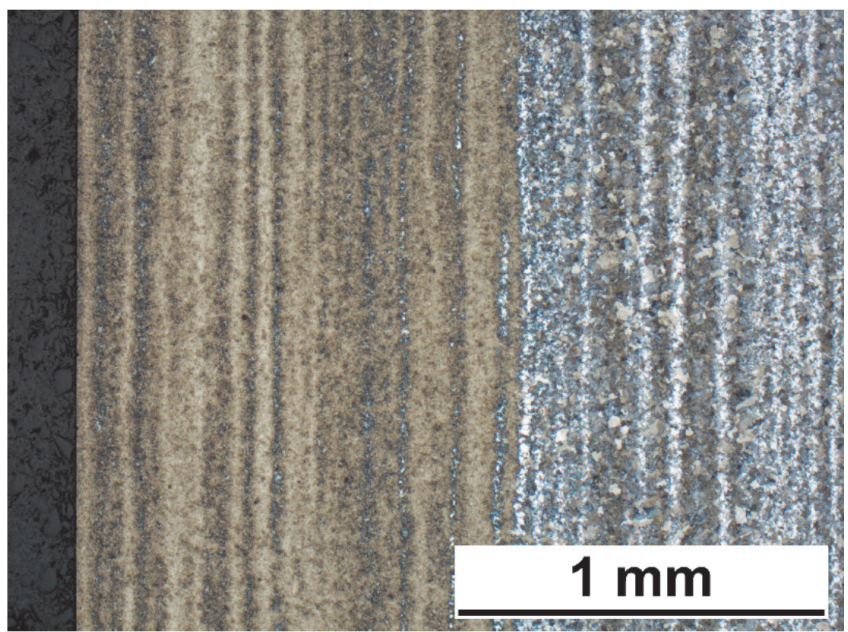

eine langreichweitige Kohlenstoffdiffusion notwendig ist. Beispielsweise fanden sich im Einsatzstahl 20MnCr5 eine Austenitkorngröße von $G=10$ in den ehemaligen Ferritzeilen und von $\mathrm{G}=12$ in den ehemaligen Perlitzeilen [64]. Neben der Korngröße kann auch die Kornform beeinflusst werden. Für einen X2CrNi12 wurde eine deutlich in Seigerungsrichtung gelängte Kornform festgestellt [65]. Ähnliches findet sich für viele Mehrphasenstähle wie Dual-Phasen- oder TRIP-Stähle.

Analog zum langsamen Abkühlen beginnt die Umwandlung beim Abschrecken in den Bereichen mit hoher kritischer Abkühlgeschwindigkeit [66]. Auch hier wandeln dann die Bereiche niedriger kritischer Abkühlgeschwindigkeit später um. Resultierendes Gefüge kann bspw. ein zeiliges bainitisch/martensitisches Gefüge sein. Vor allem bei einsatzgehärteten Bauteilen ist im Kern deshalb meist ein zeiliges bainitisch/martensitisches Gefüge vorhanden, wie Bild 13 am Beispiel 20MnCr5 zeigt. Auch bei rein martensitischem Gefüge kann die Entstehung zeilenförmig sein, da die lokale Martensitstarttemperatur von der seigerungsbedingten

Fig. 13. Banded bainite/ martensite microstructure in the core of a sample of $20 \mathrm{MnCr} 5$ due to Mn-lines

Bild 13. Durch Mn-Zeilen bedingtes zeiliges Bainit/ Martensit-Gefüge im Kern einer Probe aus $20 \mathrm{MnCr} 5$

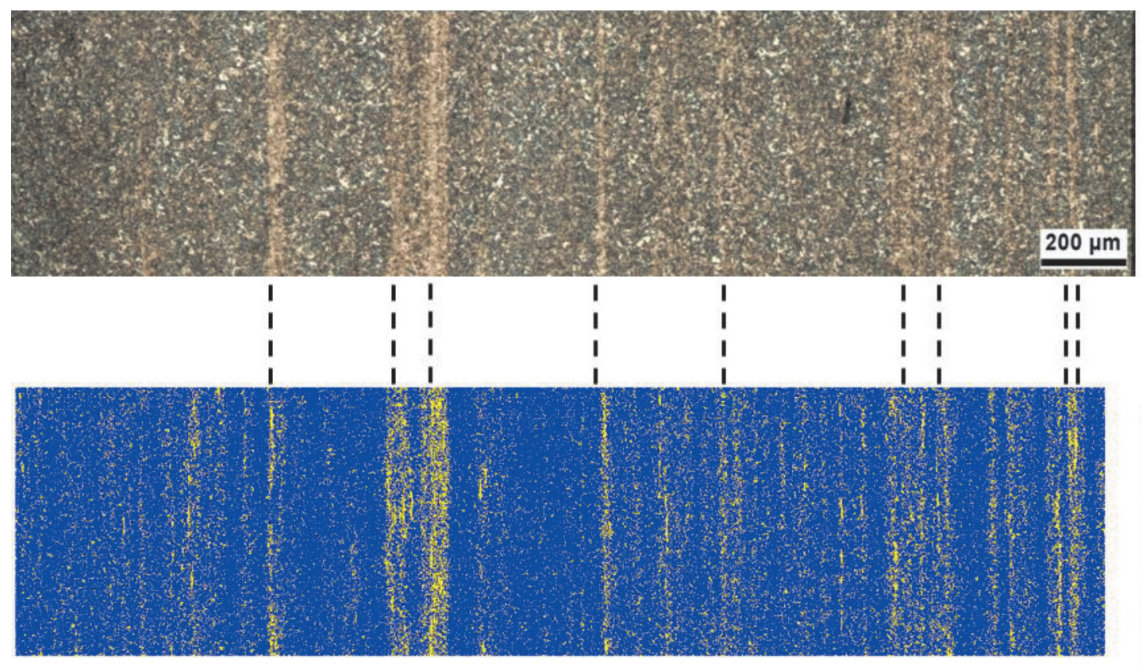

$2.6 \mathrm{~mm}$
1.6

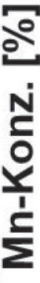


rograph, as shown in Figure $2 b$, by a fibrous expression of the microstructure, but often cannot be depicted in micrograph.

In negatively segregated bands, a ferritic or bainitic transformation can begin, although a martensitic transformation is expected due to the cooling rate in a homogeneous material. For example, massive ferrite bands were found in a component made of X20Cr13, which was supposed to undergo martensitic transformation as an air hardener [67]. This case can be prevented by an adapted, i. e. increased, cooling rate.

\subsection{Influence of macrosegregation during heat treatment}

Microsegregations have an obvious effect during heat treatment due to their banded microstructure discussed above. However, there are also effects from macrosegregations. In hardened components, a steep hardness gradient can result at the transition from the outer, dendritic to the inner, globulitic region. Figure 14 shows results of a case-hardened bevel gear blank made of $20 \mathrm{MnCr} 5$ [68]. The hardness decreases almost abruptly by $70 \mathrm{HV} 10$ at the transition from the outer to the inner region. Correspondingly, the hardness values in the inner area scatter much more strongly. For Figure 14, the hardness was determined with HV 10, since the larger area of the hardness indentation with HV 10 compared to HV 1 leads to an averaging over several bands. This transition is also clearly reflected in the etchability. The different hardness results between the outer and inner areas can be confirmed dilatometrically [68]. Here, too, at a cooling time $t_{8 / 5}=30 \mathrm{~s}$, which corresponds to the cooling rate in the component, a hardness difference of $70 \mathrm{HV} 1$ is found between dilatometer samples taken lokalen chemischen Zusammensetzung abhängt. Diese machen sich dann in einer Makroaufnahme, wie in Bild 2b gezeigt, durch eine faserige Ausprägung des Gefüges bemerkbar, lassen sich aber im Mikroschliff oft nicht darstellen.

In negativ geseigerten Zeilen kann eine ferritische oder bainitische Umwandlung beginnen, obwohl aufgrund der Abkühlgeschwindigkeit bei einem homogenen Material eine martensitische Umwandlung erwartet wird. Beispielsweise wurden in einem Bauteil aus X20Cr13, der als Lufthärter martensitisch umwandeln sollte, massive Ferritzeilen gefunden [67]. Dieser Fall lässt sich durch eine angepasste, d. h. erhöhte, Abkühlgeschwindigkeit verhindern.

\subsection{Einfluss von Makroseigerungen in der Wärmebehandlung}

Mikroseigerungen haben aufgrund ihrer oben diskutierten zeiligen Gefügeausprägung einen offensichtlichen Effekt während der Wärmebehandlung. Daneben finden sich aber auch Effekte aus den Makroseigerungen. Bei gehärteten Bauteilen kann ein steiler Härtegradient beim Übergang vom äußeren, dendritischen zum inneren, globulitischen Bereich resultieren. Bild 14 zeigt Ergebnisse eines einsatzgehärteten Kegelradrohlings aus 20MnCr5 [68]. Die Härte nimmt fast sprungartig um 70 HV 10 am Übergang vom äußeren zum inneren Bereich ab. Gleichzeitig streuen die Härtewerte im inneren Bereich deutlich stärker. Für Bild 14 wurde die Härte mit HV 10 bestimmt, da die größere Fläche des Härteeindrucks mit HV 10 gegenüber HV 1 zu einer Mittelung über mehrere Zeilen führt. Dieser Übergang findet sich auch in der Anätzbarkeit deutlich wieder. Die unterschiedlichen Härtergebnisse zwischen äußerem und innerem Bereich lassen sich dilatometrisch bestätigen [68]. Auch hier findet sich bei einer Abkühldauer $t_{8 / 5}=30 \mathrm{~s}$, die der Abkühlrate im Bauteil entspricht, ein Härteunterschied von

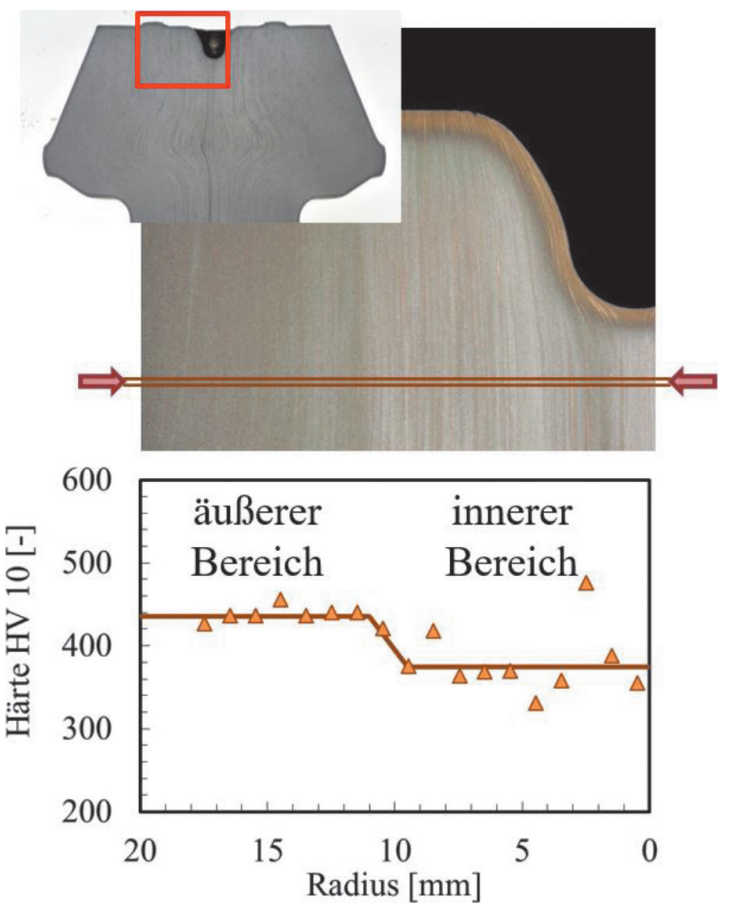

Fig. 14. Gradient in hardness and microstructure of a case-hardened bevel gear blank made of $20 \mathrm{MnCr} 5$ due to macrosegregation (hardness measurement along the line) [68]

Bild 14. Durch Makroseigerungen bedingter Gradient in Härte und Gefüge eines einsatzgehärteten Kegelradrohlings aus $20 \mathrm{MnCr} 5$ (Härtemessung entlang der Linie) [68] 
from the outer and inner areas. The reason for the lower hardness is assumed to be the different segregation state between the outer and inner area. While the outer region is rather finely distributed dendritically solidified, the inner region is coarsely globulitically solidified, see Figure 8. The elements that lower the critical cooling rate are significantly more enriched in the globulites than in the dendrites, as can also be seen in the standard deviation, Figure $4 \mathrm{~b}$. This results in a significantly higher proportion of bainite in the inner region and thus a lower martensite content than in the outer predominantly martensitic region. A consequence of the different martensite and bainite contents is a lower hardness in the inner area compared to the outer area. Similarly, the case-hardening depth CHD can vary significantly due to macrosegregation. Thus, a CHD of $0.98 \mathrm{~mm}$ was determined in the globulitic region and a CHD of $0.77 \mathrm{~mm}$ in the dendritic region with approximately identical carburisation depth and geometry [28].

\subsection{Anisotropic strain behaviour and distortion}

The banded transformation behaviour has a direct influence on the strain behaviour during austenitising. It has been shown that the transformation strain is directional in the case of a banded initial microstructure $[27,69,70]$. Figure 15 shows the change in length and diameter of a $20 \mathrm{MnCr} 5$ dilatometer specimen during heating. Since the austenite has a lower specific volume than the ferrite and pearlite, tensile stresses develop in the austenite and compressive stresses in the ferrite in the direction of the bands during the transformation of a banded microstructure. The reduction of these stresses through plastic effects such as creep, plastic hardening and transformation plasticity then leads to the anisotropic behaviour during transformation [69]. Similarly, cooling and quenching also result in anisotropic behaviour during transformations. Experimentally, it is found for $20 \mathrm{MnCr} 5$ that the transformation from or to a banded ferritic/perlitic structure shows a significantly greater anisotropic behaviour than the transformation to bainite/martensite. The decisive factor here is probably that stress relief by creep is more effective
70 HV1 zwischen aus den im äußeren und inneren Bereich entnommenen Dilatometerproben. Als Ursache für die geringere Härte wird der unterschiedliche Seigerungszustand zwischen äußeren und inneren Bereich vermutet. Während der äußere Bereich eher feinverteilt dendritisch erstarrt ist, ist der innere Bereich grob globulitisch erstarrt, s. Bild 8. Die Elemente, die die kritische Abkühlgeschwindigkeit erniedrigen, sind in den Globuliten deutlich höher angereichert als in den Dendriten, wie sich auch an der Standardabweichung, Bild 4b, zeigen lässt. Dadurch entsteht im inneren Bereich ein deutlich höherer Anteil an Bainit und somit ein niedriger Martensitgehalt als im äußeren überwiegend martensitischen Bereich. Eine Folge der unterschiedlichen Martensit- und Bainitanteile ist eine im inneren Bereich niedriger Härte verglichen mit dem äußeren Bereich. Analog dazu kann die Einsatzhärtetiefe CHD makrsoseigerungsbedingt deutlich variieren. So wurden im globulitischen Bereich eine CHD von 0,98 $\mathrm{mm}$ und im dendritischen Bereich eine $\mathrm{CHD}$ vom $0,77 \mathrm{~mm}$ bei näherungsweise identischer Aufkohltiefe und Geometrie bestimmt [28].

\subsection{Anisotropes Dehnungsverhalten und Verzug}

Das zeilige Umwandlungsverhalten hat einen direkten Einfluss auf das Dehnungsverhalten während der Austenitisierung. Es hat sich gezeigt, dass die Umwandlungsdehnung bei zeiligem Ausgangsgefüge richtungsabhängig ist $[27,69,70]$. Bild 15 zeigt die Längenund Durchmesseränderung einer Dilatometerprobe aus 20MnCr5 beim Erwärmen. Da der Austenit ein geringeres spezifisches Volumen als der Ferrit und der Perlit hat, entstehen bei der Umwandlung eines zeiligen Gefüges im Austenit Zugspannungen und im Ferrit Druckspannungen in Zeilenrichtung. Der Abbau dieser Spannungen durch plastische Effekte wie Kriechen, plastische Verfestigung und Umwandlungsplastizität führt dann zu dem anisotropen Verhalten während der Umwandlung [69]. Analog ergibt sich beim Abkühlen und Abschrecken ebenfalls ein anisotropes Verhalten während der Umwandlungen. Experimentell findet sich für $20 \mathrm{MnCr} 5$, dass die Umwandlungen aus einem oder zu einem zeiligen ferritisch/perlitischem Gefüge ein deutlich größeres anisotropes Verhalten zeigt als die Umwandlung zu Bainit/Martensit.
Fig. 15. Change in length and diameter of a dilatometer sample made of $20 \mathrm{MnCr} 5$ during heating (results in cooperation with LWT, University of Rostock)

Bild 15. Längen- und Durchmesseränderung einer Dilatometerprobe aus $20 \mathrm{MnCr} 5$ beim Erwärmen (Ergebnisse in Kooperation mit LWT, Universität Rostock)

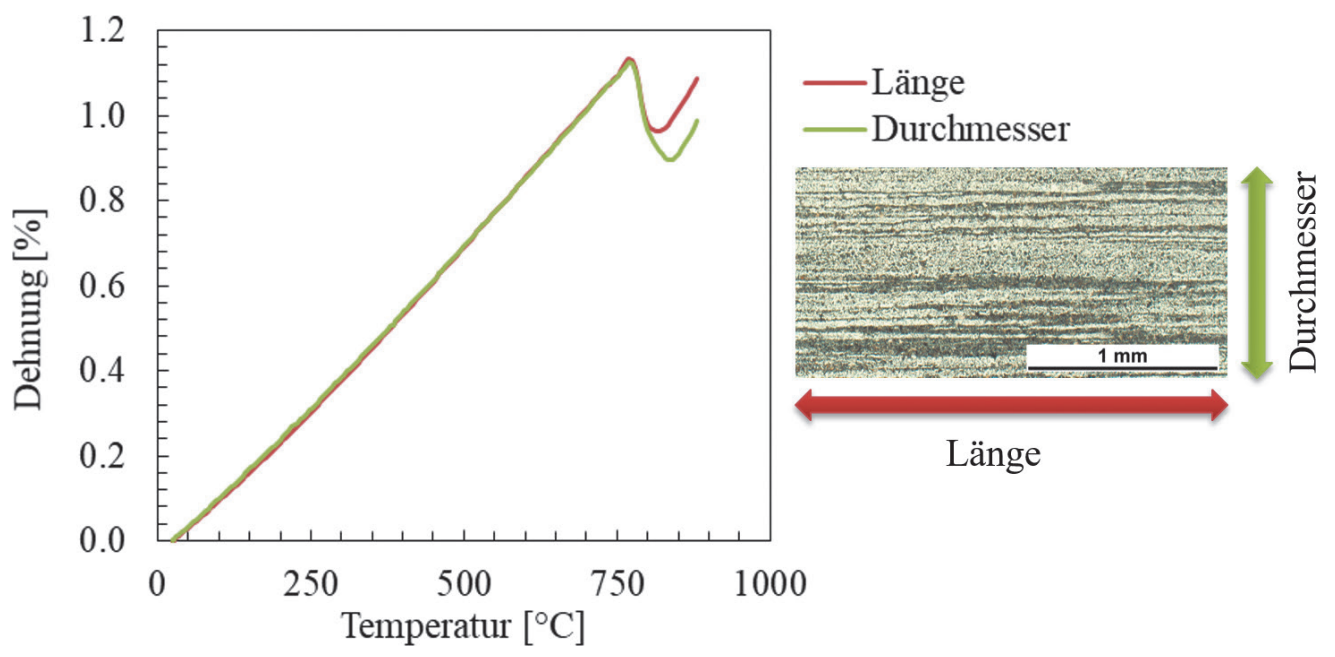


at the higher temperatures than stress relief by plastic hardening at the lower temperatures.

The anisotropic strain is particularly relevant for high-carbon, high-alloy tool steels, which have a pronounced carbide tendency [71]. The cause here is the strain hindrance during heating or cooling due to the difference in thermal strain between matrix and carbides. Thus, stresses build up during heating or quenching, which are relieved during transformation by transformation plastic effects [71]. In our own investigations on $100 \mathrm{Cr} 6$, this effect could not be reproduced despite carbide bands. Obviously, the carbide banding has to reach a certain extent before anisotropy occurs. This is especially the case with high-alloy steels. In this respect, for the same steel batch, the distortion due to segregation of a spheroidized-annealed microstructure is lower than for an ferrite-pearlite microstructure.

The anisotropic strain difference can lead to considerable distortion in components, especially if they are strongly deformed by forming processes $[56,72,73]$. This was investigated exemplarily on simple discs made of $20 \mathrm{MnCr} 5[56,73]$. The influence of the forming process in combination with the segregations could be directly demonstrated by taking identical components at three different positions from identically manufactured forged blanks and then case hardened them identically $[56,73]$. The only difference between the discs is thus the differently positioned segregation lines due to the removal (briefly referred to as the cutting strategy, Figure 16). The dishing was evaluated, which describes plate-like contour of the discs, see Figure 16. This dishing is linearly dependent on the cutting strategy. This means that the distortion can be directly traced back to the segregation lines. The cause of the uprighting could also be clearly
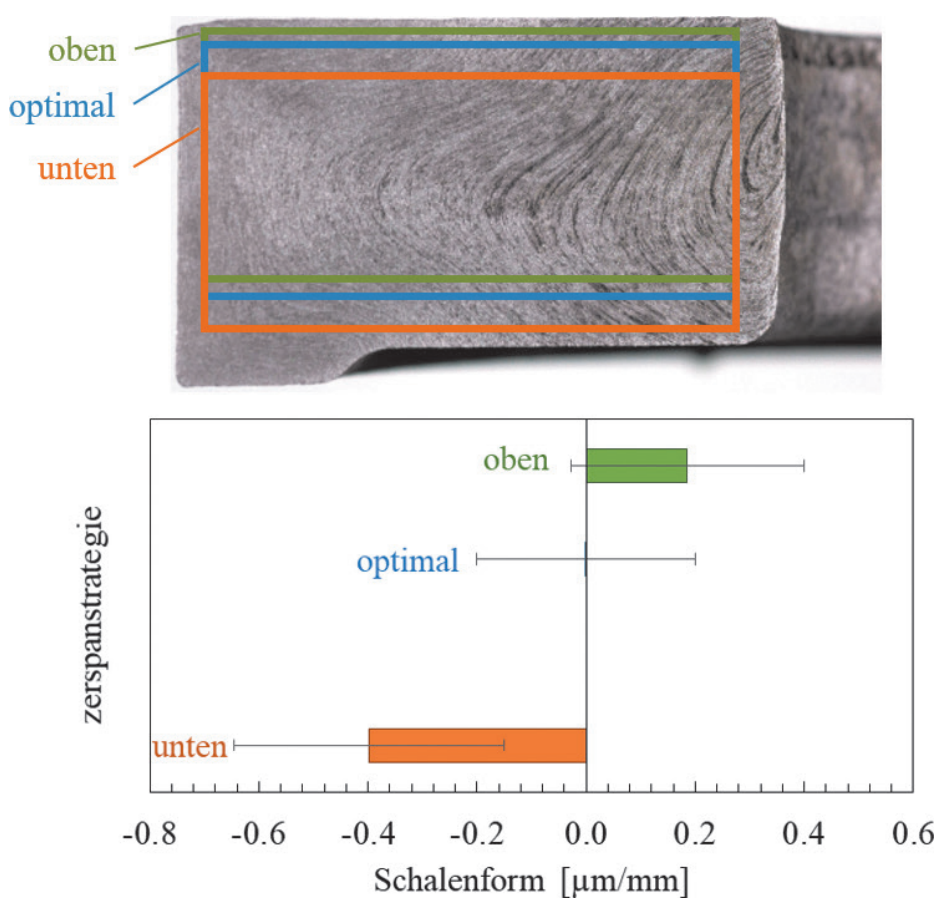

Ausschlaggebend dürfte hier sein, dass der Spannungsabbau durch Kriechen bei den höheren Temperaturen effektiver ist als der Spannungsabbau durch Verfestigung bei den tieferen Temperaturen.

Besonders relevant ist die anisotrope Dehnung bei höher kohlenstoffhaltigen, hochlegierten Werkzeugstählen, die eine ausgeprägte Karbidzeiligkeit aufweisen [71]. Ursache ist hier die Dehnungsbehinderung beim Erwärmen oder Abkühlen durch den Unterschied in der thermischen Dehnung zwischen Matrix und Karbiden. Damit bauen sich beim Erwärmen oder Abschrecken Spannungen auf, die während der Umwandlung durch umwandlungsplastische Effekte abgebaut werden [71]. Bei eigenen Untersuchungen an $100 \mathrm{Cr} 6$ konnte dieser Effekt trotz Karbidzeilen nicht reproduziert werden. Die Karbidzeiligkeit muss offensichtlich ein gewisses Ausmaß annehmen, bevor eine Anisotropie aufritt. Dies ist vor allem bei hochlegierten Stählen der Fall. Insofern ist bei gleicher Stahlcharge der seigerungsbedingte Verzug eines GKZGefüges geringer als bei einem FP-Gefüge.

Der anisotrope Dehnungsunterschied kann in Bauteilen zu erheblichen Verzug führen, insbesondere wenn diese durch Umformprozesse stark verformt sind $[56,72,73]$. Exemplarisch wurde das an einfachen Scheiben aus $20 \mathrm{MnCr} 5$ untersucht $[56,73]$. Der Einfluss des Umformprozesses in Kombination mit den Seigerungen liess sich unmittelbar nachweisen, indem aus identisch gefertigten Schmiederohlingen identische Bauteile an drei unterschiedlichen Positionen entnommen wurden und dann identisch einsatzgehärtet wurden [56, 73]. Der einzige Unterschied zwischen den Scheiben ist damit die aufgrund der Entnahme unterschiedlich positionierten Seigerungslinien (kurz als Zerspanstrategie bezeichnet, Bild 16). Ausgewertet wurde die Schalenform, die das Auftellern der Scheiben beschreibt, s. Bild 16. Diese Schalenform ist linear von der Zerspanstrategie abhängig. Damit lässt sich der Verzug unmittelbar auf die Seigerungslinien zurückfüh-
Fig. 16. Shell shape of $20 \mathrm{MnCr} 5$ discs taken differently from the semi-finished product during case hardening [56]

Bild 16. Schalenform von unterschiedlich aus dem Halbzeug entnommen Scheiben aus $20 \mathrm{MnCr} 5$ während der Einsatzhärtung [56] 
assigned to the anisotropic strain difference via a simulation study [72].

\subsection{Abnormal grain growth and hardening cracks due to inhomogeneous precipitation distribution}

Segregated structures can cause an inhomogeneous distribution of precipitates [74]. Precipitates often form preferentially in the positively segregated regions and are significantly less present in the negatively segregated regions. For example, $\mathrm{TiC}$ in carbon steel alloyed with $\mathrm{Ti}$ are found preferentially in the interdentritic regions [75]. Both the increased formation in the positively segregated regions and the lower fraction in the negatively segregated regions can lead to problems during heat treatment.

Segregation-related inhomogeneous precipitate formation has been associated with abnormal austenite grain growth $[53,54$, 75-78]. For example, a correlation between coarse grain growth and a banded microstructure was found on a steel roughly equivalent to a $20 \mathrm{Mn} 4$ [53]. Abnormal grain growth occurred as early as 30 min austenitising at $900{ }^{\circ} \mathrm{C}$. The abnormal grain growth essentially starts in the former ferrite bands. Non-uniform pinning due to inhomogeneous $\mathrm{AlN}$ or $\mathrm{Nb}(\mathrm{C}, \mathrm{N})$ distribution was postulated as an explanation. In the negative bands, the existence range for the precipitates is shifted to significantly lower temperatures and the volume fraction is lower [54]. In this case, the precipitated fraction may be locally too low for effective pinning. A homogenisation annealing of $3 \mathrm{~h}$ at $1300{ }^{\circ} \mathrm{C}$ prevented a banded microstructure and abnormal grain growth [53]. In principle, it can initially neither be ruled out that the precipitates were insufficiently adjusted in the preheating treatment, nor that they dissolved again during hardening. The cause of insufficient, segregation-related precipitation is likely to depend on the individual case.

Hardening cracks are always a problem, especially when hardening components. Apart from obvious faults such as sharp notches or excessively harsh quenching, there are indications that hardening cracks often occur when a number of reinforcing negative influencing factors coincide. These include an unfavourable quenching intensity, a banded microstructural transformation and non-metallic inclusions. The necessity of several negative influencing variables naturally makes it difficult to assign a clear cause. For a gear shaft made of $18 \mathrm{CrNiMo} 7-6$, hardening cracks were attributed to a pronounced banding in combination with excessive quenching [79]. In the case of the quenched and tempered steel 50CrMo4, hardening cracks were only found in a batch with increased S content and thus increased manganese sulphide $(\mathrm{MnS})$ content [80]. In contrast, a low-S, MnS-free batch showed no hardening cracks. With MnS, poor bonding to the matrix and a low coefficient of thermal expansion come together. As a result, $\mathrm{MnS}$ can act as internal notches and lead to cracks in case of unfavourable stress formation. At the same time, a banded transformation leads to addi- ren. Die Ursache des Auftellerns konnte über eine Simulationsstudie auch eindeutig dem anisotropen Dehnungsunterschied zugeordnet werden [72].

\subsection{Abnormales Kornwachstum und Härterisse durch inhomogene Ausscheidungsverteilung}

Geseigerte Strukturen können eine inhomogene Verteilung von Ausscheidung bedingen [74]. Die Ausscheidungen bilden sich oft bevorzugt in den positiv geseigerten Bereichen und sind in den negativ geseigerten Bereichen deutlich geringer vorhanden. Beispielsweise finden sich $\mathrm{TiC}$ in mit Ti legierten Kohlenstoffstahl bevorzugt in den interdentritischen Bereichen [75]. Sowohl die verstärkte Bildung in den positiv geseigerten Bereichen als auch der geringere Anteil in den negativ geseigerten Bereichen kann bei der Wärmebehandlung zu Problemen führen.

Seigerungsbedingte inhomogene Ausscheidungsbildung wird mit abnormalen Austenitkornwachstum in Verbindung gebracht [53, 54, 75-78]. So wurde eine Korrelation zwischen dem groben Körnern und einem zeiligen Gefüge an einem Stahl, der in etwa einem 20Mn4 entspricht, festgestellt [53]. Abnormales Kornwachstum trat schon bei einer Austenitisierung von $30 \mathrm{~min}$ bei $900{ }^{\circ} \mathrm{C}$ auf. Das abnormale Kornwachstum beginnt im Wesentlichen in den ehemaligen Ferritbändern. Als Erklärung wurde ein ungleichmäßiges Pinnen durch eine inhomogene $\operatorname{AlN}$ oder $\mathrm{Nb}(\mathrm{C}, \mathrm{N})$ Verteilung postuliert. In den negativen Zeilen ist der Existenzbereich für die Ausscheidungen zu deutlich niedrigeren Temperaturen verschoben und der Volumenanteil niedriger [54]. Dabei kann der ausgeschiedene Anteil lokal zu niedrig für ein effektives Pinnen sein. Durch ein Homogenisierungsglühen von $3 \mathrm{~h}$ bei $1300{ }^{\circ} \mathrm{C}$ konnte ein zeiliges Gefüge und ein abnormales Kornwachstum verhindert werden [53]. Prinzipiell kann zunächst weder ausgeschlossen werden, dass die Ausscheidungen in der Vorwärmebehandlung unzureichend eingestellt wurden, noch dass sie sich beim Härten wieder auflösten. Die Ursache unzureichender, seigerungsbedingter Ausscheidungen dürfte vom Einzelfall abhängig sein.

Probleme stellen immer wieder Härterisse insbesondere beim Härten von Bauteilen dar. Von eindeutigen Fehlern wie scharfe Kerben oder zu schroffe Abschreckung abgesehen, deutet sich an, dass Härterisse oftmals beim Zusammentreffen mehrerer sich verstärkender negativer Einflussgrößen auftreten. Hierzu gehören eine ungünstige Abschreckintensität, eine zeilige Gefügeumwandlung und nichtmetallische Einschlüsse. Die Notwendigkeit mehrerer, negativer Einflussgrößen erschwert natürlich eine eindeutige Ursachenzuordnung. Für eine Zahnradwelle aus 18CrNiMo7-6 wurden Härterisse auf eine ausgeprägte Zeiligkeit im Zusammenspiel mit einer zu starken Abschreckung zurückgeführt [79]. Beim Vergütungsstahl 50CrMo4 wurden Härterisse nur bei einer Charge mit erhöhtem S-Gehalt und damit gesteigerten Mangansulfidgehalten $(\mathrm{MnS})$ gefunden [80]. Dagegen zeigte eine S-arme, MnSfreie Charge keine Härterisse. Bei MnS kommen eine schlechte Anbindung an die Matrix und ein niedriger thermischer Ausdehnungskoeffizient zusammen. Dadurch können MnS als innere Kerben wirken und bei ungünstiger Spannungsausbildung zu Rissen führen. Gleichzeitig führt eine zeilige Umwandlung zu zusätz- 
tional stress contributions that are superimposed on the stresses due to the thermal gradient.

\section{Influence of segregation and banded microstructure on component properties}

Segregations and the resulting banded microstructure have a manifold influence on component properties. The microstructural inhomogeneities occurring during heat treatment and the resulting distortion have already been described in Chapter 7 during heat treatment. Segregations and their orientation related to force application can have a great influence during impact loading or during service life determination.

In the case of a DP600 multiphase steel, which was present in a banded ferritic-martensitic microstructure, crack initiation was detected during a tensile test in the more brittle martensitic phase [23]. This is analogous to the cold extrusion cracking described in Chapter 6.3 when bainite or martensite bands are present in a ferrite/perlite microstructure. For $20 \mathrm{Mn} 5$ with different $\mathrm{S}$ contents, a dependence of the impact energy on the MnS orientation and the $S$ content is found [81]. A higher impact energy was found at lower $S$ content or when the impact direction was perpendicular to the elongated MnS. On the other hand, different ferrite/pearlite band structure had no influence on the notched impact energy. Thus, the orientation and number of $\mathrm{MnS}$ influences the impact energy but not a banded microstructure.

After the forming processes, $\mathrm{MnS}$ are found elongated in the direction of segregation in the rolling direction [82], which is why there are studies on the orientation influence on the service life. From the literature, service life investigations perpendicular and parallel to the segregations are known for the steels En7A $(\sim 20 \mathrm{Mn} 5+S)$ [83], 25MnCrSiVP6 [84], 27MnCrS5 [82] and 50CrMo4 with two $S$ contents [85]. The Wöhler curve of service life sample taken perpendicular to the rolling direction and thus to the longitudinal direction of the MnS is clearly below the Wöhler curve of service life samples taken in parallel [83-85]. Since MnS in particular are often found in the Mn-rich rows and are elongated in the row direction [82], it is often impossible to distinguish between the microstructural bands and the $\mathrm{MnS}$ as the cause of failure [15]. For the user, the distinction is also secondary. But it is found that the more pronounced the segregations are, the more $\mathrm{MnS}$ are present. In this context, the initial cross-section of the solidification geometry and the $\mathrm{S}$ as well as $\mathrm{Mn}$ content of the alloy also play a role. For the various reasons mentioned above, care should be taken to ensure a representative segregation formation in the test cross-section, both in component design and in service life testing.

The outer area of a rolled bar of continuously cast $20 \mathrm{MnCr} 5$ shown in Figure 8 is usually more homogeneous than the inner area. Particularly to improve mechanical properties, design and process planning can be such that the segregation distribution is optimised. Loaded areas should be located in this outer region if possible. Often it is already sufficient that segregation lines run paral- lichen Spannungsbeiträgen, die den Spannungen aufgrund des thermischen Gradienten überlagert sind.

\section{Einfluss von Seigerungen und zeiligem Gefüge auf Bauteileigenschaften}

Seigerungen und die daraus folgenden zeilige Gefügestruktur haben einen vielfältigen Einfluss auf Bauteileigenschaften. Die während der Wärmebehandlung auftretende Gefügeinhomogenitäten und der daraus resultierende Verzug wurden schon in Kapitel 7 bei der Wärmebehandlung beschrieben. Einen großen Einfluss können Seigerungen und ihre Orientierung zur Krafteinleitung bei schlagartiger Belastung oder bei der Lebensdauerbestimmung haben.

Bei einem Mehrphasenstahl DP600, der in einem zeiligen ferritisch-martensitischen Gefüge vorlag, wurde die Rissinitiierung während eines Zugversuchs in der spröderen martensitischen Phase festgestellt [23]. Das erfolgt analog zu dem in Kapitel 6.3 beschriebenen Rissen beim Kaltfließpressen, wenn Bainit- oder Martensitzeilen in einem Ferrit/Perlit-Gefüge vorliegen. Bei 20Mn5 mit verschiedenen S-Gehalten findet sich eine Abhängigkeit der Kerbschlagarbeit zur MnS-Orientierung und dem S-Gehalt [81]. Eine höhere Kerbschlagarbeit ergab sich bei niedrigerem S-Gehalt oder wenn die Schlagrichtung senkrecht zu den gelängten MnS war. Für verschiedene Ferrit/Perlit-Zeiligkeiten fanden sich dagegen keinen Einfluss auf die Kerbschlagarbeit. Damit beeinflusst die Orientierung und Anzahl der MnS die Kerbschlagarbeit, aber nicht ein zeiliges Gefüge.

Nach den Umformprozessen finden sich MnS in Seigerungsrichtung in Walzrichtung gelängt [82], weshalb es Untersuchungen zum Orientierungseinfluss auf die Lebensdauer gibt. Aus der Literatur sind Lebensdaueruntersuchungen senkrecht und parallel zu den Seigerungen für die Stähle En7A ( 20Mn5+S) [83], 25MnCrSiVP6 [84], 27MnCrS5 [82] und 50CrMo4 mit zwei S-Gehalten [85] bekannt. Die Wöhlerkurve senkrecht zur Walzrichtung und damit zur Längsrichtung der MnS entnommen Lebensdauerproben liegt deutlich unter der Wöhlerkurve von parallel entnommen Lebensdauerproben [83-85]. Da insbesondere MnS oft in den Mn-reichen Zeilen zu finden und in Zeilenrichtung gelängt sind [82], ist es oft unmöglich, zwischen der Gefügezeiligkeit und den MnS als Ursache für ein Versagen zu unterscheiden [15]. Für den Anwender ist die Unterscheidung auch zweitrangig. Aber es findet sich, dass umso ausgeprägter die Seigerungen sind, desto mehr MnS sind vorhanden. In diesem Zusammenhang spielt der Ausgangsquerschnitt der Erstarrungsgeometrie und der S- sowie Mn-Gehalt der Legierung auch eine Rolle. Aus den verschiedenen zuvor genannten Gründen sollte sowohl bei der Bauteilauslegung als auch bei Lebensdauerprüfung auf eine repräsentative Seigerungsausbildung im Prüfquerschnitt geachtet werden.

Der in Bild 8 dargestellte äußere Bereich eines Walzstabs aus stranggegossenen $20 \mathrm{MnCr} 5$ ist meist homogener als der innere Bereich. Besonders zur Verbesserung der mechanischen Eigenschaften können Konstruktion und Prozessplanung so gestaltet sein, dass die Seigerungsverteilung optimiert wird. Belastete Bereiche sollten nach Möglichkeiten in diesen äußeren Bereich gele- 
lel to the loaded surfaces. It is unfavourable if segregation lines emerge perpendicular to the surface. In order to achieve the most favourable fibre flow, cold extrusion can be helpful, as only a small amount of material removal is necessary. These measures cannot be implemented for all component geometries.

\section{Conclusions and possible measures to reduce segregation effects along the process chain}

Segregation is a phenomenon for which the entire process chain of the production of steel components must be considered. Various aspects play a role in the formation of segregation: the chemical inhomogeneities that can arise during primary shaping, the strong deformations during rolling and forging, cutting during machining and an inhomogeneous microstructure resulting from segregation after heat treatment or after welding, which is not dealt with here. Due to the segregations, microstructural constituents can occur that are not expected in chemically homogeneous material. At the same time, segregations can cause damage in various processes: susceptibility to cracking especially in cold flow processes, quenching cracks during hardening, distortion and inhomogeneous hardness distribution after heat treatment or crack initiation in the service life range. Since segregation cannot be avoided in common primary shaping processes for thermodynamic reasons, the detrimental consequences in particular must be taken into account when planning production.

Table 2 summarises measures to reduce the negative effects of segregation in the process chain. It has not been taken into account that these measures may be contrary to other conditions in manufacturing. Some measures may not always be feasible for cost or technological reasons. In addition, some measures are now state of the art and are already routinely applied. The measures can be divided into three groups:

- Reduction of segregation

- Reduction of microstructure bands

- Reduction of the effect through a more favourable arrangement of microstructure bands

In the case of critical components, segregation-related effects should already be taken into account during the design phase and corresponding specifications made with regard to steel quality and individual process steps. By using qualified manufacturers, defined manufacturing routines and an exact specification, an attempt can be made to set the segregation distribution in the component in a reproducible manner. In this way, a reduction of the negative effect of segregations is achieved if they are positioned uncritically. By metallographically determining the segregation gen sein. Oft ist es bereits ausreichend, dass Seigerungslinien parallel $\mathrm{zu}$ den belasteten Oberflächen verlaufen. Ungünstig ist einzuschätzen, wenn Seigerungslinien senkrecht an der Oberfläche austreten. Um einen möglichst günstigen Faserverlauf einzustellen, kann hierbei das Kaltfließpressen hilfreich sein, da hier nur ein geringer Materialabtrag durchs Zerspanen notwendig ist. Diese Maßnahmen lassen sich nicht bei allen Bauteilgeometrien verwirklichen.

\section{Schlussfolgerungen und möglichen Maßnahmen zur Reduzierung von Seigereffekten entlang der Prozesskette}

Seigerungen sind ein Phänomen, bei dem die gesamte Prozesskette der Fertigung von Stahlbauteilen betrachtet werden muss. Hierbei spielen verschiedene Aspekte bei der Entstehung eine Rolle: die chemischen Inhomogenitäten, die beim Urformen entstehen können, die starken Verformungen beim Walzen und Schmieden, ein Anschneiden beim Zerspanen sowie ein aus den Seigerungen resultierendes inhomogenes Gefüge nach einer Wärmebehandlung oder nach dem hier nicht behandeltem Schweißen. Dabei können aufgrund der Seigerungen Gefügebestandteile auftreten, die bei chemisch homogenem Material nicht erwartet werden. Gleichzeitig können Seigerungen eine Schädigung bei verschiedenen Prozessen bewirken: Rissanfälligkeit insbesondere bei Kaltfließprozessen, Abschreckrisse beim Härten, Verzug und inhomogene Härteverteilung nach der Wärmebehandlung oder Rissinitiierung im Bereich der Lebensdauer. Da sich Seigerungen bei üblichen Urformprozessen aus thermodynamischen Gründen nicht vermeiden lassen, sind insbesondere die schädlichen Konsequenzen bei der Planung der Fertigung zu berücksichtigen.

In Tabelle 2 sind Maßnahmen zur Reduzierung negativer Auswirkungen von Seigerungen in der Prozesskette zusammengefasst. Dabei wurde nicht berücksichtigt, dass diese Maßnahmen konträr zu anderen Bedingungen in der Fertigung sein können. Einige Maßnahmen werden sich aus Kostengründen oder technologische Gründen nicht immer umsetzen lassen. Außerdem entsprechen einige Maßnahmen mittlerweile dem Stand der Technik und werden heute schon routinemäßig angewendet. Die Maßnahmen lassen sich dabei in drei Gruppen gliedern:

- Reduzierung von Seigerungen

- Reduzierung der Gefügezeiligkeiten

- Reduzierung der Auswirkung durch eine günstigere Anordnung von Gefügezeiligkeiten

Bei kritischen Bauteilen sollten bereits während der Konstruktion seigerungsbedingte Effekte berücksichtigt werden und entsprechende Vorgaben hinsichtlich Stahlgüte und einzelne Prozessschritte gemacht werden. Durch Rückgriff auf qualifizierte Hersteller, definierte Herstellroutinen und eine genaue Spezifikation kann versucht werden, die Seigerungsverteilung im Bauteil reproduzierbar einzustellen. Damit wird eine Verringerung der negativen Auswirkung von Seigerungen erreicht, wenn diese unkritisch positioniert werden. Durch eine metallographische Bestimmung der 


\begin{tabular}{|c|c|c|}
\hline Prozessschritt & Maßnahme & Wirkung \\
\hline Konstruktion & $\begin{array}{c}\text { Berücksichtigung von Seigerungen } \\
\text { - belastete Bereiche möglichst in seigerungsarme Bereiche } \\
\text { - Gefügezeilen parallel zur belasteten Oberfläche } \\
\text { - Seigerungen bei der Auslegung berücksichtigen } \\
\text { - Auswirkung von Seigerungen auf den Verzug }\end{array}$ & $\begin{array}{l}\text { Verbesserung des Wärmebehandlungsergebnisses } \\
\text { Erhöhung der Lebensdauer }\end{array}$ \\
\hline Stahlauswahl & Spezifikation und Herstellerwahl & $\begin{array}{l}\text { reproduzierbarere Seigerungsausbildung und damit } \\
\text { Verringerung einer negativen Auswirkung von Seigerungen }\end{array}$ \\
\hline Stahlauswahl & $\begin{array}{l}\text { unter Berücksichtigung von Seigerungen abgestimmtes } \\
\text { Härtbarkeitsstreuband } \\
\end{array}$ & Vermeidung ungünstiger Gefügebestandteile \\
\hline Stahlauswahl & schwefelarme Stähle & $\begin{array}{c}\text { geringerer Anteil an Sulfiden in zeiliger Anordnung und damit } \\
\text { Verringerung der Rissanfälligkeit }\end{array}$ \\
\hline Urformen & $\begin{array}{l}\text { optimale Gießbedingung } \\
\text { elektromagnetisches Rühren } \\
\text { Soft Reduction } \\
\end{array}$ & Verringerung der Seigerungen \\
\hline Urformen & Strangguss statt Blockguss & gleichmäßigere Seigerungsausbildung \\
\hline nach Urformen & ESU-/VAR-Material & seigerungsarmes Material \\
\hline vor Umformen & Diffusionsglühen & Abbau von Mikroseigerungen \\
\hline Umformen & $\begin{array}{l}\text { Halbzeuggeometrie } \\
\text { Umformabfolge }\end{array}$ & $\begin{array}{l}\text { Verschieben schädlicher Seigerungen in unkritische } \\
\text { Bauteilbereiche }\end{array}$ \\
\hline Umformen & endformnahes Umformen & Gefügezeiligkeit parallel zur Oberfläche \\
\hline Wärmebehandlung & $\begin{array}{c}\text { Verzicht auf zeiliges Ausgangsgefüge } \\
- \text { GKZ } \\
\text { - vorvergütet } \\
\text { - nichtzeiliges FP-Gefüge }\end{array}$ & $\begin{array}{l}\text { homogenere Austenitisierung } \\
\text { Verringerung des Verzugs }\end{array}$ \\
\hline Wärmebehandlung & $\begin{array}{l}\text { Seigerungen bei Austenitisierdauer und Abkühlbedingung } \\
\text { berücksichtigen }\end{array}$ & $\begin{array}{l}\text { keine negativen Gefügebestandteile } \\
\text { - Martensitzeilen in FP } \\
\text { - Ferritzeilen im gehärteten Gefüge }\end{array}$ \\
\hline Quantifizierung & $\begin{array}{l}\text { Metallographische Dokumentation der Seigerungs- } \\
\text { verteilung nach einzelnen Fertigungsschritten }\end{array}$ & $\begin{array}{l}\text { Identifizierung kritischer oder unzulässiger } \\
\text { Seigerungsverteilungen }\end{array}$ \\
\hline $\begin{array}{l}\text { Probenentnahme } \\
\text { (ZTU-Diagramm, } \\
\text { Lebensdauer, etc.) }\end{array}$ & $\begin{array}{c}\text { Seigerungen bei der Probenentnahme berücksichtigen } \\
\text { - Richtungsabhängigkeit (Zeiligkeit) } \\
\text { - Makroseigerungen }\end{array}$ & $\begin{array}{l}\text { repräsentatives Ergebnis } \\
\text { Verringerung der Streuung }\end{array}$ \\
\hline
\end{tabular}

Table 2. Measure to reduce negative impacts of segregation in the process chain. Costs and technological constraints were not taken into account

Tabelle 2. Maßnahme zur Reduzierung negativer Auswirkungen von Seigerungen in der Prozesskette. Nicht berücksichtigt wurden dabei Kosten und technologische Zwänge

distribution, for example by macro etching or Baumann imprint, after individual process steps, these can be documented. This allows critical or impermissible segregation distributions to be identified. The risk of unfavourable microstructural constituents can be reduced by a coordinated hardenability scatter band that also takes segregations into account. These measures must be matched to the component and process route. By using low-sulphur steels, it is also possible to reduce the density of linearly formed sulphides, which are more likely to initiate cracks. Today, the state of the art is measures in the steelworks to reduce segregation. These include optimal casting conditions, electromagnetic stirring and soft reduction. The subsequent reduction of segregation via ESU / VAR material or diffusion annealing is also state of the art, but requires
Seigerungsverteilung nach einzelnen Prozessschritten, beispielsweise durch Makroätzung oder Baumannabdruck, können diese dokumentiert werden. Dadurch lassen sich kritische oder unzulässige Seigerungsverteilungen identifizieren. Durch ein abgestimmtes Härtbarkeitsstreuband, bei dem auch Seigerungen berücksichtigt werden, kann die Gefahr ungünstiger Gefügebestandteile verringert werden. Diese Maßnahmen müssen dabei auf Bauteil und Prozessroute abgestimmt sein. Durch den Einsatz von schwefelarmen Stählen lässt sich zudem die Dichte an zeilig eingeformten und damit verstärkt rissinitiierenden Sulfiden reduzieren. Stand der Technik sind heute Maßnahmen im Stahlwerk zur Reduzierung von Seigerungen. Dazu gehören optimale Gießbedingung, elektromagnetisches Rühren und Soft Reduction. Auch die 
one more energy-intensive process step. In many cases, the negative effects of segregation can be avoided by reducing the microstructure banding. A banded ferrite/pearlite structure can lead to inhomogeneous austenitising states and can also be a major contributor to distortion. Optimised ferrite-pearlite annealing can often significantly reduce this lineation. An alternative is to replace it with a quenched and tempering or spheroidized annealing, which usually lead to significantly more homogeneous microstructures. Pronounced positive or negative microsegregations can lead to undesirable microstructural bands such as martensite after ferrite-pearlite annealing or ferrite after hardening. Therefore, possible positive or negative microsegregations should be taken into account when selecting the cooling or quenching condition. By optimising the design and manufacturing process, microstructural bands can ultimately be brought into a more favourable arrangement. By optimising the semi-finished product geometry and the forming sequence, an attempt can be made to shift harmful segregation areas into non-critical component areas. Microstructural bands should lie as parallel as possible to the loaded surface. This can be achieved by forming close to the final shape. While external toothing is usually located in the less critical, bandpoor area, internal toothing or holes are often found in areas with strong bands. If no other measures can be implemented, the design must be chosen according to the segregation. When samples are manufactured to determine material properties, segregations must be taken into account. This includes, for example, dilatometer specimens for recording a TTT diagram or specimens for fatigue testing. Both the directional dependence to the microsegregations and the positioning due to macrosegregations have to be taken into account. This results in a more representative result. At the same time, the scatter is significantly reduced because different segregation states are not mixed.

\section{Acknowledgement}

The numerous metallographic and electron microscopic images were were taken by the Department of Metallographic Analysis carried out at the Leibniz-Institut für Werkstofforientierte Technologien - IWT. We would like to thank the staff for their for their commitment. The dilatometer measurement (Fig. 15) was carried out at the at the Chair of Materials Technology at the University of Rostock. We would also like to express our sincere thanks here. nachträgliche Reduzierung der Seigerungen über ESU-/VAR-Material oder durch ein Diffusionsglühen ist Stand der Technik, bedarf aber einen energieintensiven Prozessschritt mehr. Vielfach lassen sich negative Auswirkungen von Seigerungen durch Reduzierungen der Gefügezeiligkeit vermeiden. Eine zeilige Ferrit/Perlit-Struktur kann zu inhomogenen Austenitisierzuständen führen und kann zudem einen großen Beitrag zum Verzug haben. Durch ein optimiertes FP-Glühen lässt sich diese Zeiligkeit oft deutlich reduzieren. Eine Alternative ist der Ersatz durch eine Vorvergütung oder GKZ-Glühung, die meist zu deutlich homogeneren Gefüge führen. Ausgeprägte positive oder negative Mikroseigerungen können zu unerwünschten Gefügezeilen wie Martensit nach dem FP-Glühen oder Ferrit nach dem Härten führen. Bei der Wahl der Abkühl- bzw. Abschreckbedingung sollten deshalb mögliche positive oder negative Mikroseigerungen berücksichtigt werden. Durch Optimierung des Konstruktions- und Fertigungsprozesses lassen sich letztlich Gefügezeilen in eine günstigere Anordnung bringen. Durch Optimierung der Halbzeuggeometrie und der Umformabfolge kann versucht werden, schädliche Seigerungsbereiche in unkritische Bauteilbereiche zu verschieben. Gefügezeilen sollten möglichst parallel zur belasteten Oberfläche liegen. Das kann durch eine endformnahe Umformung geschehen. Während eine Außenverzahnung meist im weniger kritischen, zeilenarmen Bereich liegt, finden sich eine Innenverzahnung oder Bohrungen oft in Bereichen mit starken Zeiligkeiten wieder. Wenn sich keine anderen Maßnahmen realisieren lassen, ist die Auslegung seigerungsgerecht zu wählen. Wenn Proben zur Bestimmung von Materialeigenschaften gefertigt werden, müssen Seigerungen berücksichtigt werden. Hierzu gehören beispielweise Dilatometerproben zur Aufnahme eines ZTU-Diagramms oder Proben für die Lebensdaueruntersuchung. Dabei sind sowohl die Richtungsabhängigkeit zu den Mikroseigerungen als auch die Positionierung aufgrund von Makroseigerungen zu berücksichtigen. Dadurch ergibt sich ein repräsentativeres Ergebnis. Gleichzeitig wird die Streuung deutlich reduziert, da verschiedene Seigerungszustände nicht gemischt werden.

\section{Danksagung}

Die zahlreichen metallographischen und elektronenmikroskopischen Aufnahmen wurden von der Abteilung Metallographische Analytik am Leibniz-Institut für Werkstofforientierte Technologien - IWT durchgeführt. Den Mitarbeiter/innen sei herzlich für ihr Engagement gedankt. Die Dilatometermessung (Bild 15) wurde am Lehrstuhl für Werkstofftechnik der Universität Rostock durchgeführt. Auch hier sei herzlich gedankt. 


\section{References}

1. DIN: Eisenwerkstoffe - Wärmebehandlung - Begriffe (DIN EN ISO 4885), Beuth, Berlin, 2018

2. Kirkaldy, J. S.; Destinon-Forstmann, J. von; Brigham, R. J.: Simulation of Banding in Steels. Canadian Metallurgical Quarterly 1 (1962) 1, pp. 59-81, DOI:10.1179/ cmq.1962.1.1.59

3. Hoffmann, F.; Kleff, J.: Prozessketteneinflüsse auf die Wärmebehandlung. HTM J. Heat Treatm. Mat. 72 (2017) 1, pp. 50-61, DOI:10.3139/105.110312

4. Verhoeven, J.D.: A Review of Microsegregation Induced Banding Phenomena in Steels.J.Mater.Eng.Perf.9(2000)3,pp. 286-296,DOI:10.1361/105994900770345935

5. Samuels, L. E.: Optical microscopy of carbon steels. American Soc. for Metals, Metals Park, Ohio, 1980. - ISBN: 0871700824

6. Hunkel, M.; Walter, F; Rickers, M.: Metallographic Investigation of the Intrinsic Heat Treatment in the Additive Manufacturing of the Steel X40CrMoV5-1. Pract. Metall. 57 (2020) 5, pp. 304-320, DOI:10.3139/147.110623

7. Rose, A.; Boer, H. de; Hougardy, H. P.: Entmischung der Legierungselemente bei der dendritischen Erstarrung von Eisenwerkstoffen. A. Eisenhüttenw. 39 (1968) 11, pp. 829-836, DOI:10.1002/srin.196803597

8. Flemings, M. C.: Solidification processing. Metall. Trans. B 5 (1974) 10, pp. 21212134, DOI:10.1007/BF02643923

9. Schwerdtfeger, K.: Bildung von Makroseigerungen. Metallurgie des Stranggiessens: Giessen und Erstarren von Stah. K. Schwerdtfeger (Ed.), Stahleisen, Düsseldorf, 1992, pp. 171-209. - ISBN: 3-514-00350-5

10. Pickering, E. J.: Macrosegregation in Steel Ingots: The Applicability of Modelling and Characterisation Techniques. ISIJ Int. 53 (2013) 6, pp. 935-949, DOI:10.2355/ isijinternational.53.935

11. Dahl, W.: Strangguss. Leistungsvermögen hochbeanspruchter Bauteile für die Antriebstechnik. VDI-Verl., Düsseldorf, 1991. - ISBN: 3184011976

12. Wünnenberg, K.; Jacobi, H.: Formation and Sedimentation of globulites in continuous casting. A. Eisenhüttenw. 54 (1983) 6, pp. 217-222, DOI:10.1002/srin. 198305229

13. Kirkwood, D. H.: Microsegregation. Mater. Sci. Eng. 65 (1984) 1, pp. 101-109, DOI:10.1016/0025-5416(84)90204-0

14. Bersch, B.; Boer, H. de; Brand, W. D.; Ehrhardt, H.; Flossdorf, F. J.; Gebel, W.; Gulden, H.; Koehler, H. J.; Richter, K.-J.; Roth, G.: Einfluss der Seigerungen bei Strangguss auf die Werkstoffeigenschaften. stahl u. eisen 106 (1986) 7, pp. 323-331

15. Krauss, G.: Solidification, segregation, and banding in carbon and alloy steels. Metall. Trans. B 34 (2003) 6, pp. 781-792, DOI:10.1007/s11663-003-0084-z

16. Spies, H.-J.; Siegel, U.: Einfluß der Konzentrationsverteilung im Mikrobereich auf die BestimmungdesSeigerungskoeffizienten vonStählen mitdemElektronenstrahlmikroanalysator. Krist. Techn. 8 (1973) 10, pp. 1189-1196, DOI:10.1002/crat.19730081013

17. Preßlinger, H.; Mayr, M.; Kaltenbrunner, T.; Lettner, J.: Quantitative assessment of segregates in continuously cast slabs by electron probe microanalysis. steel res. 73 (2002) 4, pp. 149-156, DOI:10.1002/srin.200200187

18. Cicutti, C.; Bilmes, P.; Boeri, R.: Estimation of primary dendrite arm spacings in continuous casting products. Scripta Mater. 37 (1997) 5, pp. 599-604, DOI:10.1016/ S1359-6462(97)00148-6

19. Boccalini, M.; Goldenstein, H.: Solidification of high speed steels. Int. Mater. Reviews 46 (2001) 2, pp. 92-115, DOI:10.1179/095066001101528411

20. Verein Deutscher Eisenhüttenleute: Stahl-Eisen-Prüfblätter des Vereins Deutscher Eisenhüttenleute - SEP 1520. Mikroskopische Prüfung der Carbidausbildung in Stählen mit Bildreihen. Verl. Stahleisen, Düsseldorf, 1978

21. Adishesha, P. K.: Effect of Steel Making and Processing Parameters on Carbide Banding in Commercially Produced ASTM A-295 52100 Bearing Steel. Bearing Steel Technology: STP1419; J. M. Beswick (Ed.), ASTM, West Conshohocken, PA, USA, 2002, pp. 27-46

22. From, A.; Sandström, R.: Assessment of Banding in Steels by Using Advanced Image Analysis. Mater. Char. 41 (1998) 1, pp. 11-26, DOI:10.1016/S1044-5803(98)00019-9

23. Tasan, C. C.; Hoefnagels, J. P. M.; Geers, M. G. D.: Microstructural banding effects clarified through micrographic digital image correlation. Scripta Mater. 62 (2010) 11, pp. 835-838, DOI:10.1016/j.scriptamat.2010.02.014

24. Krebs, B.; Hazotte, A.; Germain, L.; Gouné, M.: Quantitative analysis of banded structures in dual-phase steels. Image Anal. Stereol. 29 (2010) 2, pp. 85-90, DOI:10.5566/ias.v29.p85-90
25. ASTM: Standard Practice for Assessing the Degree of Banding or Orientation of Microstructures (ASTM E-1268), ASTM Int., West Conshohocken, PA, USA, 2019

26. Peter, W.; Finkler, H.: Betrachtungen über Möglichkeiten zur Erzielung eines zeilenfreien Gefüges. HTM Härterei-Techn. Mitt. (1961) 16, pp. 51-60

27. Hunkel, M.; Frerichs, F.; Prinz, C.; Surm, H.; Hoffmann, F.; Zoch, H.-W.: Size Change due to Anisotropic Dilation Behaviour of a Low Alloy SAE 5120 Steel. steel research int. 78 (2007) 1, pp. 45-51, DOI:10.1002/srin.200705858

28. Hunkel, M.: Analyse von Seigerungen und seigerungsbedingtem Verzug am Beispiel des Einsatzstahls 20MnCr5. HTM J. Heat Treatm. Mat. 67 (2012) 5, pp. 311-322, DOI:10.3139/105.110162

29. Peter, W.; Finkler, H.; Kohlhaas, E.: Entstehung und Beseitigung besonderer Karbidseigerungen in Werkzeugstählen mit rd. 1 \% C. A. Eisenhüttenw. 41 (1970) 8, pp. 749-756, DOI:10.1002/srin.197001654

30. Oettel, H.; Schumann, H.: Metallografie. Mit einer Einführung in die Keramografie. 15., überarb. und erw. Aufl.; Wiley-VCH, Weinheim, 2011. - ISBN: 9783527322572

31. Stewart, J. W.; Charles, J.A.; Wallach, E. R.: Iron-phosphorus-carbon system: Part 2 - Metallographic behaviour of Oberhoffer's reagent. Mater. Sci. Techn. 16 (2000) 3, pp. 283-290, DOI:10.1179/026708300101507848

32. Stefanescu, D. M.; Ruxanda, R.: Fundamentals of Solidification. Metallography and Microstructures; G. F. Vander Voort (Ed.); ASTM International, West Conshohocken, PA, USA, 2004; pp 71-92. - ISBN: 978-1-62708-177-1

33. Schrewe, H.: Stranggießen von Stahl. Einführung und Grundlagen. Stahleisen, Düsseldorf, 1987. - ISBN: 3514003475

34. Flemings, M. C.: Our Understanding of Macrosegregation. Past and Present. ISIJ Int. 40 (2000) 9, pp. 833-841, DOI:1 0.2355/isijinternational.40.833

35. Jung, H.-P.; Kremer, K.-J.; Spitzer, H.; Vöge, H.; Hentrich, R.: Metallurgische und verfahrenstechnische Grundlagen des Knüppelstranggiessens von Edelstählen. stahl u. eisen 104 (1984), pp. 197-204

36. Gerdom, K. H.; Kaiser, H.P.; Weber, L.; Redenz, B.; Rüttiger, K.: Elektromagnetisches Rühren im Sekundärkühlbereich von Brammenstranggießanlagen. stahl u. eisen 104 (1984) 9, pp. 435-441

37. Wünnenberg, K.; Jacobi, H.: Metallurgische Probleme beim elektromagnetischen Rühren von Stahl während der Erstarrung. stahl u. eisen 97 (1977), pp. 1075-1081

38. Thome, R.; Harste, K.: Principles of Billet Soft-reduction and Consequences for Continuous Casting. ISIJ Int. 46 (2006) 12, pp. 1839-1844, DOI:10.2355/ isijinternational.46.1839

39. Thome, R.; Harste, K.; Richter, K.-J.; Ney, G.: Einsatz von Soft Reduction bei der Herstellung von Langprodukten. stahl u. eisen 132 (2012) 3, pp. 61-67

40. Harste, K.; Klingbeil, J.; Schmitz, W.; Weyer, A.; Hartmann, R.: Neubau einer Vertikalstranggießanlage bei der AG der Dillinger Hüttenwerke. stahl u. eisen 117 (1997) 11, pp. 73-79

41. Lesoult, G.: Macrosegregation in steel strands and ingots: Characterisation, formation and consequences. Mater. Sci. Eng. A 413-414 (2005), pp. 19-29, DOI:10.1016/j.msea.2005.08.203

42. Fredriksson, H.; Nilsson, S. O.: On the formation of macrosegregations in ingots. Metall. Trans. B 9 (1978) 1, pp. 111-120, DOI:10.1007/BF02822678

43. Moore, J. J.; Shah, N. A.: Mechanisms of formation of A- and V-segregation in cast steel. Int. Met. Rev. 28 (1983) 1, pp. 336-356, DOI:10.1179/imtr.1983.28.1.336

44. Bauckhage, K.; Schulz, A.; Uhlenwinkel, V.: Verallgemeinerungsfähige Merkmale und Besonderheiten des Sprühkompaktierens. Mat.-wiss. u. Werkstofftech. 34 (2003) 1, pp. 6-12, DOI:10.1002/mawe.200390019

45. Arh, B.; Podgornik, B.; Burja, J.: Electroslag remelting: a process overview. Mater. Technol. 50 (2016) 6, pp. 971-979, DOI:10.17222/mit.2016.108

46. Holzgruber, W.; Plöckinger, E.: Metallurgische und verfahrenstechnische Grundlagen des Elektroschlacke-Umschmelzens von Stahl. stahl u. eisen 88 (1968) 12, pp. 638-648

47. Mitchell, A.: Solidification in remelting processes. Mater. Sci. Eng. A 413-414 (2005), pp. 10-18, DOI:10.1016/j.msea.2005.08.157

48. Zanner, F. J.: Metal transfer during vacuum consumable arc remelting. Metall. Trans. B 10 (1979) 2, pp. 133-142, DOI:10.1007/BF02652456

49. Ward, R. G.: Effect of Annealing on the Dendritic Segregation of Manganese in Steel. J.Iron Steel Inst. 203 (1965) 9, pp. 930-932

50. Purdy, G. R.; Kirkaldy, J. S.: Homogenization by diffusion. Metall. Trans. B 2 (1971) 2, pp. 371-378, DOI:10.1007/BF02663324 
51. Prinz, C.; Rentsch, R.: Experimental investigation concerning the development of distortion potential during the production of $20 \mathrm{MnCr} 5$. Mat.-wiss. u. Werkstofftech. 43 (2012) 1-2, pp. 63-67, DOI:10.1002/mawe.201100889

52. Eisbrecher, I.; Clausen, B.; Hunkel, M.; Rentsch, R.: Anisotropies and inhomogeneities in the microstructure of the case hardening steel SAE 5120. Mat.-wiss. u. Werkstofftech. 43 (2012) 1-2, pp. 78-83, DOI:10.1002/mawe.201100892

53. Zhang, X.; Matsuura, K.; Ohno, M.: Abnormal Grain Growth in Austenite Structure Reversely Transformed from Ferrite/Pearlite-Banded Structure. Metall. Mat. Trans. A 45 (2014) 10, pp. 4623-4634, DOI:10.1007/s11661-014-2364-4

54. Wang, F.; Davis, C.; Strangwood, M.: Grain growth on reheating for an as-cast Al-Nb-containing steel with segregated composition. Mater. Sci. Techn. 35 (2019) 5, pp. 615-627, DOI:10.1080/02670836.2019.1577533

55. Ramazani, A.; Ebrahimi, Z.; Prahl, U.: Study the effect of martensite banding on the failure initiation in dual-phase steel. Comp. Mater. Sci. 87 (2014), pp. 241-247, DOI:10.1016/j.commatsci.2014.01.051

56. Brinksmeier, E.; Lübben, T.; Fritsching, U.; Cui, C.; Rentsch, R.; Sölter, J.: Distortion minimization of disks for gear manufacture. Int. J. Mach. Tool Manu. 51 (2011) 4, pp. 331-338, DOI:10.1016/j.ijmachtools.2010.12.005

57. Dictra; Thermo-Calc Software, 2020, www.thermocalc.com

58. Thompson, S. W.; Howell, P. R.: Factors influencing ferrite/pearlite banding and origin of large pearlite nodules in a hypoeutectoid plate steel. Mater. Sci. Techn. 8 (1992) 9, pp. 777-784, DOI:10.1179/mst.1992.8.9.777

59. Kaspar, R.; Chen, Q.; Streißelberger, A.: Gefügezeiligkeit in Warmbreitband aus mikrolegiertem Baustahl. A. Eisenhüttenw. 54 (1983) 7, pp. 273-276, DOI:10.1002/ $\operatorname{srin} .198305241$

60. Großterlinden, R.; Kawalla, R.; Lotter, U.; Pircher, H.: Formation of pearlitic banded structures in ferritic-pearlitic steels. steel res. 63 (1992) 8, pp. 331-336, DOI:10.1002/srin.199200529

61. Speich, G. R.; Demarest, V. A.; Miller, R. L.: Formation of Austenite During Intercritical Annealing of Dual-Phase Steels. Metall. Mat. Trans. A 12 (1981) 8, pp. 1419-1428, DOI:10.1007/BF02643686

62. Caballero, F. G.; García-Junceda, A.; Capdevila, C.; García de Andrés, C.: Evolution of Microstructural Banding during the Manufacturing Process of Dual Phase Steels. Mater. Trans. 47 (2006) 9, pp. 2269-2276, DOI:10.2320/matertrans.47.2269

63. McGarrity, K. S.; Sietsma, J.; Jongbloed, G.: Characterisation and quantification of microstructural banding in dual phase steels Part 1 - General 2D study. Mater. Sci. Techn. 28 (2012) 8, pp. 895-902, DOI:10.1179/1743284712Y.0000000004

64. Prinz, C.; Clausen, B.; Hoffmann, F.; Kohlmann, R.; Zoch, H.-W.: Metallurgical influence on distortion of the case-hardening steel $20 \mathrm{MnCr} 5$. Mat.-wiss. u. Werkstofftech. 37 (2006) 1, pp. 29-33, DOI:10.1002/mawe.200500949

65. Knutsen, R. D.: Influence of compositional banding on grain anisotropy in 3CR12 steel. Mater. Sci. Techn. 8 (1992) 7, pp. 621-627, DOI:10.1179/mst.1992.8.7.621

66. Penha, R. N.; Vatavuk, J.; Couto, A. A.; Pereira, S. A. d. L.; Sousa, S. A. de; Canale, L. d. C. F.: Effect of chemical banding on the local hardenability in AISI 4340 steel bar. Engineering Failure Analysis 53 (2015), pp. 59-68, DOI:10.1016/j.engfailanal. 2015.03.024

67. Neidel, A.; Fischer, B.; Leggemann, S.: The Metallurgical Causes of Structural Inhomogeneities in Hot Rolled Bars of Martensitic $12 \%$ Chromium Steels. Pract. Metall. 49 (2012) 3, pp. 171-184, DOI:10.3139/147.110169

68. Hunkel, M.; Kagathara, J.; Prahl, U.: The Influence of Segregations after Forming on the Heat Treatment Result of Bevel Gears. steel research int. 90 (2019) 6, 1800427, DOI:10.1002/srin.201800427

69. Hunkel, M.: Anisotropic transformation strain and transformation plasticity: two corresponding effects. Mat.-wiss. u. Werkstofftech. 40 (2009) 5-6, pp. 466-472, DOI:10.1002/mawe.200900478

70. Kop, T. A.; Sietsma, J.; van der Zwaag, S.: Anisotropic dilatation behaviour during transformation of hot rolled steels showing banded structure. Mater. Sci. Techn. 17 (2001) 12, pp. 1569-1574, DOI:10.1179/026708301101509629
71. Wei, J.; Kessler, O.; Hunkel, M.; Hoffmann, F.; Mayr, P.: Anisotropic phase transformation strain in forged D2 tool steel. Mater. Sci. Techn. 20 (2004) 7, pp. 909-914, DOI:10.1179/026708304225019641

72. Şimşir, C.; Eisbrecher, I.; Hunkel, M.; Lübben, T.; Hoffmann, F.: The Prediction of the Distortion of Blank-Hardened Gear Blanks by Considering the Effect of Prior Manufacturing Operations. Steel Res. Intern. Spec. Proc. 10 ${ }^{\text {th }}$ ed. ICTP2011 (2011), 25.-30.09.11, Aachen, Germany, G. Hirt, E. A. Tekkaya (eds.), Stahleisen, Düsseldorf, 2011 pp. 199-204

73. Rentsch, R.: Verzugsentstehung bei Scheiben aus $20 \mathrm{MnCr} 5$ - Einfluss von Umformung und Gefügestruktur. HTM J. Heat Treatm. Mat. 67 (2012) 5, pp. 323-330, DOI:10.3139/105.110166

74. Roy, S.; Patra, S.; Neogy, S.; Laik, A.; Choudhary, S. K.; Chakrabarti, D.: Prediction of Inhomogeneous Distribution of Microalloy Precipitates in Continuous-Cast High-Strength, Low-Alloy Steel Slab. Metall. Mat. Trans. A 43 (2012) 6, pp. 18451860, DOI:10.1007/s11661-011-1045-9

75. Titov, A. O.; Inoue, R.; Suito, H.: Grain-growth-inhibiting Effects of $\mathrm{TiC}$ and $\mathrm{ZrC}$ Precipitates in Fe-0.15 0.30mass\%C Alloy. ISIJ Int. 48 (2008) 3, pp. 301-309, DOI:10.2355/isijinternational.48.301

76. Legat, A.: Der Aussagewert der Korngröße über den Homogenitätsgrad des Gefüges und als Umwandlungsverhalten von Stählen. HTM Härterei-Techn. Mitt. 15 (1960) 4, pp. 218-222

77. Kundu, A.; Davis, C.; Strangwood, M.: Grain Size Distributions after Single Hit Deformation of a Segregated, Commercial Nb-Containing Steel: Prediction and Experiment. Metall. Mat. Trans. A 42 (2011) 9, pp. 2794-2806, DOI:10.1007/ s11661-011-0712-1

78. Roy, S.; Karmakar, A.; Mukherjee, S.; Kundu, S.; Srivastava, D.; Chakrabarti, D.: Effect of starting microstructure on austenite grain sizes developed after reheating of HSLA steel. Mater. Sci. Techn. 30 (2014) 10, pp. 1142-1153, DOI:10.1179/1743 284713Y.0000000385

79. D’Errico, F.: Failures Induced by Abnormal Banding in Steels. J. Fail. Anal. Preven. 10 (2010) 5, pp. 351-357, DOI:10.1007/s11668-010-9374-3

80. Temmel, C.; Karlsson, B.; Ingesten, N.-G.: Quenching cracks in medium carbon steel initiated at manganese sulfide inclusions. HTM Z. Werkst. Wärmebeh. Fertigung 62 (2007) 5, pp. 236-242, DOI:10.3139/105.100429

81. Spitzig, W. A.: Effect of sulfide inclusion morphology and pearlite banding on anisotropy of mechanical properties in normalized C-Mn steels. Metall. Mat. Trans. A 14 (1983) 1, pp. 271-283, DOI:10.1007/BF02651624

82. Wang, K.; Yu, T.; Song, Y.; Li, H.; Liu, M.; Luo, R.; Zhang, J. Y.; Fang, F. S.; Lin, X.: Effects of MnS Inclusions on the Banded Microstructure in Non-quenched and Tempered Steel. Metall. Trans. B 50 (2019) 3, pp. 1213-1224, DOI:10.1007/s11663-019-01532-0

83. Kaynak, C.; Ankara, A.; Baker, T. J.: Inclusion induced anisotropy of short fatigue crack growth in steel. Mater. Sci. Techn. 12 (1996) 7, pp. 557-562, DOI:10.1179/ mst.1996.12.7.557

84. Pessard, E.; Morel, F.; Verdu, C.; Flacelière, L.; Baudry, G.: Microstructural heterogeneities and fatigue anisotropy of forged steels. Mater. Sci. Eng. A 529 (2011), pp. 289-299, DOI:10.1016/j.msea.2011.09.031

85. Temmel, C.; Karlsson, B.; Ingesten, N.-G.: Fatigue Isotropy in Cross-Rolled, Hardened Isotropic-Quality Steel. Metall. Mat. Trans. A 39 (2008) 5, pp. 1132-1144, DOI:10.1007/s11661-008-9467-8

\section{Bibliography}

DOI:10.1515/htm-2020-0006

HTM J. Heat Treatm. Mat.

76 (2021) 2; page 79-104

(C) 2021 Walter de Gruyter GmbH, Berlin/Boston, Germany

ISSN 1867-2493, e-ISSN 2194-1831 